\title{
Comparative social demography, livelihood diversification and land tenure among the Maasai of Kenya and Tanzania
}

David K. Nkedianye ${ }^{1,2 \dagger}$, Joseph O. Ogutu ${ }^{1,3^{*}+}$, Mohammed Y. Said ${ }^{1,4,5}$, Shem C. Kifugo ${ }^{1,6}$, Jan de Leeuw ${ }^{1,7}$, Paul Van Gardingen ${ }^{2}$ and Robin S. Reid ${ }^{1,8}$

\begin{abstract}
We analyse social demography, livelihood diversification and land tenure among the Maasai people inhabiting Kenya (three sites) and Tanzania (one site) with contrasting land tenure policies. In Kenya, land was communally owned in the rural Amboseli, fully privatized in the peri-urban Kitengela in Athi-Kaputiei and partially privatized and communally owned in the rural Maasai Mara. In Tanzania, the government owned the land but granted user rights to local villages in rural Simanjiro in Tarangire-Manyara. We interviewed 100 households per site from May to July 2006. There were regional distinctions in social demography, livelihood diversification, hiring herding labour and settlement arrangements, portraying differential transition away from traditional pastoral Maasai society. The transition is most advanced in Kitengela located near Nairobi City, where privatization of land tenure in the 1980s triggered land sub-division, unprecedented land fragmentation and large-scale collapse of the commons, pastoralism and conservation. Land privatization and sub-division in Maasai Mara and Amboseli started in 2000s and were followed similarly by unprecedented fragmentation through fences and accelerated collapse of the commons, pastoralism and conservation, except where wildlife conservancies were later established. We found several differences at the household, regional and national levels. The average age of household heads was lower in Maasai Mara and Amboseli than in Kitengela and Simanjiro. The average number of wives per male household head was lowest in Kitengela, intermediate in Mara and Amboseli and highest in Simanjiro. Correspondingly, the mean number of children per family was lowest in Kitengela, intermediate in Mara and Amboseli and highest in Simanjiro. Household heads were more educated closer to urban centres. Household heads without formal education were thus most common in Amboseli, intermediate in Mara and Simanjiro and fewest in Kitengela. Livelihood diversification was marked in all the sites. Notably, cultivation was widespread and most of those interviewed were interested in crop cultivation. The average number of acres cultivated per household was far higher in Simanjiro than in all the other sites. The mean number of hired herders per household was higher in Kitengela, with the highest number of children enrolled in schools, than in the Mara, Amboseli or Simanjiro. The average number of households per settlement was highest in the Mara, intermediate in Amboseli and Simanjiro (Continued on next page)
\end{abstract}

\footnotetext{
* Correspondence: jogutu2007@gmail.com

${ }^{\dagger}$ David K Nkedianye and Joseph O. Ogutu are joint first authors.

'International Livestock Research Institute, P.O. Box 30709, Nairobi 00100,

Kenya

${ }^{3}$ University of Hohenheim, Institute for Crop Science-340, Biostatistics Unit,

70599 Stuttgart, Germany

Full list of author information is available at the end of the article
}

\section{Springer Open}

(c) The Author(s). 2020 Open Access This article is licensed under a Creative Commons Attribution 4.0 International License, which permits use, sharing, adaptation, distribution and reproduction in any medium or format, as long as you give appropriate credit to the original author(s) and the source, provide a link to the Creative Commons licence, and indicate if changes were made. The images or other third party material in this article are included in the article's Creative Commons licence, unless indicated otherwise in a credit line to the material. If material is not included in the article's Creative Commons licence and your intended use is not permitted by statutory regulation or exceeds the permitted use, you will need to obtain permission directly from the copyright holder. To view a copy of this licence, visit http://creativecommons.org/licenses/by/4.0/. 
(Continued from previous page)

and lowest in Kitengela. The marked regional variation in social demography, livelihood diversification and land

tenurial arrangements reflects underlying variation in proximity to urban centres, agro-climatological and national developmental and policy environments.

Keywords: Maasai, Social demography, Livelihood diversification, Land tenure, Settlement arrangements, Crop cultivation, Climate change, Kenya and Tanzania, Africa

\section{Highlights}

- Household heads were more educated closer to than further from urban centres among the Maasai of Kenya and Tanzania

- Polygyny and wives per male household head were lower whereas the numbers of children enrolled in school were higher closer to urban centres.

- Livelihood diversification from pastoralism to cultivation was common across all sites.

- The average number of hired herders was higher closer to urban centres, corresponding to higher school enrolment.

- The number of households per settlement was lower farther from than closer to urban centres.

\section{Introduction}

Maasai pastoralists, like other pastoralists, are changing rapidly (Coast 2002; Thompson 2002; Worden 2007; Sachedina 2008; BurnSilver 2009; Galvin 2009; Nkedianye et al. 2009; Reid et al. 2014). These changes and the associated challenges pose monumental difficulties to pastoralism, making its future precarious (Prins 1992). Among the key drivers of change are environmental factors such as frequent and severe droughts (Maloiy and Heady 1965; Campbell 1999; Willis 1999; Fratkin 2001), land use and tenure changes. Land privatization (BurnSilver and Mwangi 2007; Worden 2007) accelerates land fragmentation and conversion to non-pastoral uses (Kimani and Pickard 1998; Reid et al. 2008; Nkedianye et al. 2009) and thereby weakens the viability of pastoralism as an exclusive livelihood practice (Archambault 2011). Additional key drivers of change are human population growth in the marginal lands, inside and outside the pastoral systems (Sindiga 1984; Waller 1985; Galaty 1993); state neglect; political and economic marginalization; and land dispossession by colonial and post-colonial states (Galaty 1992; Lane 1994; Archambault 2011). Although social change is a continuous process and difficult to measure for such complex social units as communities (Merzel and D'afflitti 2003), the dynamism of the pastoral socio-economic and policy environments is accelerating change and pushing more pastoralists out of their 'traditional' ways of life (Homewood et al. 2009a). This exacerbates poverty and human vulnerability to biophysical and other shocks (Lesorogol 2005; UNEP and GoK 2006).

The trajectories of change in pastoral areas such as Maasailand are complex and, together with rising pressures, are fundamentally altering the lives and livelihoods of many Maasai (Meinzen-Dick and Mwangi 2009; Thompson et al. 2009). Among the Maasai of southern Kenya and northern Tanzania, these changes increasingly strain the pillars that have supported pastoralism for millennia. Thus, family-supplied labour for herding, for example, is declining, as more youth are enrolled in schools and therefore unavailable for long periods of their youth when they are most needed for herding (Spencer 1998).

While large families were once considered necessary and even prestigious, polygyny is generally declining (Talle 1988; Coast 2002). A key source of influence has been western education and the teachings of Christianity (Coles 2008; Baird 2015), non-governmental organizations (NGOs) and state-funded family planning programmes. In addition, pastoral household heads are finding it increasingly difficult to support larger families today as the cash economy exerts unprecedented demand for money on most aspects of Maasai life. Consequently, in most parts of Maasailand, families are experiencing a rising demand for money that is often unmatched by the available cash income sources, primarily from livestock sales (McCabe et al. 2014). The social and economic structures (e.g. norms of reciprocity between friendship and kinship ties ensuring mutual support in times of difficulties) that have traditionally supported widows and other less endowed members of the Maasai community are also weakening. As a result, poverty is increasing, engendering a high dependency ratio (Siringi 2009).

The trajectory of change across pastoral areas is tending away from the time-tested traditional ways into manifold livelihood strategies (Homewood et al. 2009b). Diversification of livelihood options beyond livestock-keeping is now widespread in all pastoral areas (Thompson and Homewood 2002; Radeny et al. 2007; Sachedina 2008; BurnSilver 2009). In response to the changing times, Maasai pastoralists are also diversifying into different livelihood activities. These range from petty trade, charcoal burning, wage employment, cultivation, building rental 
houses in shopping centres and leasing out their land to other people for conservation and farming to various types of businesses (Kristjanson et al. 2002; Thompson 2002; Sachedina 2008; Homewood et al. 2009b). Others are engaged in the mining industry, land speculation or brokerage activities, especially in areas of high agricultural and development potential. The effects of these changes are amplified by increasing climatic variability and government land use policies that have historically favoured agriculture over pastoralism, coupled with rising demographic pressures on the land. However, the transition from tested ways to new untested ones is fraught with difficulties and uncertainties so that many families find it increasingly difficult to avoid or escape once they fall into the poverty trap (McCabe 2003; Homewood et al. 2009b; McCabe et al. 2014).

Land tenure change in Kenya and Tanzania has been strongly influenced by colonial and post-colonial government policies that are inimical to mobile pastoralism and favour sedentarization. For example, the colonial government established most conservation set-asides, with a few gazetted in the post-colonial era (Brockington 2005). The post-colonial land tenure system was a carryover from the colonial system rooted in western theories of land tenure (Homewood et al. 2009a) which exalt individual title above other modes of ownership. In Tanzania, the post-colonial government promoted socialist land tenure policies, communal ownership and villagization-(usually compulsory) resettlement of people into designated villages by government or military authorities. In the post-independence period, uncontrolled land use and demand for land by an exponentially growing population have led to the loss of most of the dry season grazing lands to cultivation, fences and settlements and unviable land sub-divisions (Kimani and Pickard 1998; Lamprey and Reid 2004; Reid et al. 2008). Other land uses include the expansion of towns and cities and horticultural and floricultural industries (Said et al. 2016). Land privatization in pastoral areas of Kenya has also triggered a surge in land sales and purchases. The Kenya government's policy on land sub-division and privatization has also driven mass dispossession of communities and heightened land speculation and land grabbing by elites (Galaty 1992; Mwangi 2007a, 2007b; Meinzen-Dick and Mwangi 2009; Thompson et al. 2009). In Tanzania, land use policies have led to massive conversion of pasture land from extensive pasture into subsistence and commercial crop cultivation (Sachedina 2008). The situation is worsened by asymmetries of political and economic power and knowledge within and between communities that favour the more powerful elites in the new capitalist systems.

Despite the major changes in pastoralism, few comprehensive studies have comparatively analysed how differences in land tenure policies between Kenya and Tanzania, land tenure arrangements, rural or peri-urban location and agroclimatic potential among regions can help characterize processes and/or triggers of change and inform pastoral policies. Such a comparative analysis is also crucial to understanding the key drivers of change across the four pastoral systems and the conditions under which extensive pastoralism and biodiversity conservation can continue to thrive. Although badly needed for Maasailand, such in-depth regional comparison has not been previously undertaken. This region could well foreshadow the future of pastoralism elsewhere. Studying social-demographic, livelihood, tenure and settlement characteristics and how they vary spatially in this region can yield insights into future trajectories of intensifying and diversifying pastoral systems in Maasailand and elsewhere. This study is the first of its kind to undertake these assessments throughout Maasailand. It provides a broader look at issues that have previously been examined in detail in only single sites, for example, Amboseli (Campbell 1984, 1999).

We address three main questions, namely (i) to what extent are the household social-demographic characteristics similar across the rural Amboseli, peri-urban Kitengela and rural Maasai Mara regions of Kenya and the rural Simanjiro region of Tanzania? (ii) How diversified are the sources of livelihoods in the four sites, and (iii) How similar or different are the settlement and land tenure arrangements across the sites? Answers to these questions are important for understanding the nature and general direction of change (through comparison with existing literature) and assessing the implications of the changes in Maasailand and possibly other pastoral societies.

\section{Materials and methods \\ Study sites}

The study was undertaken in four sites (Fig. 1) within Maasailand, three in Kenya (Amboseli, Kitengela in Athi-Kaputiei and Mara) and one in Tanzania (Simanjiro in Tarangire-Manyara). Maasailand is the vast region of Maa-speaking peoples stretching over southern Kenya and northern Tanzania (Spear 1993; Sutton 1993). The predominant Maasai sections occupying the four sites speak a common Maa language (Table 1, Holland 1996, Spencer 1998). The four sites were selected to represent important biophysical, geographical, demographic and policy contexts and to enable a reliable comparison of the socio-cultural and economic characteristics of the three Maasai sections.

The primary source of livelihood in Maasailand is livestock pastoralism (Homewood and Rodgers 1991; Homewood et al. 2009a, 2009b), with the main species kept being cattle, sheep, goats and donkeys. The pastoralists and agro-pastoralists in Maasailand are heavily 


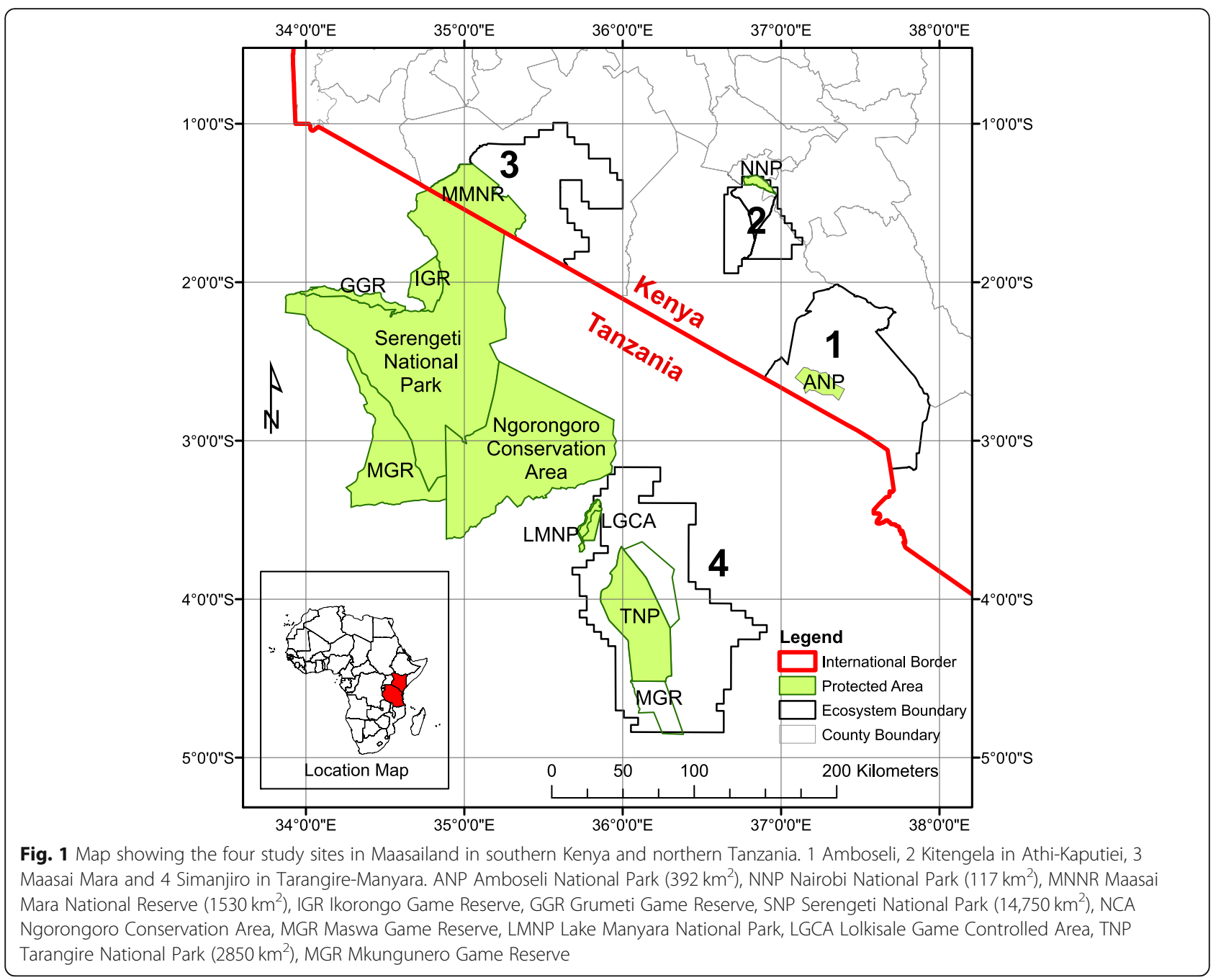

dependent on livestock for their food security. Wildlife is also present at all four sites, each of which has a large dispersal area adjacent to a protected area. Maasailand hosts several of the world's signature conservation areas (Fig. 1). Large herds of wildlife are also found in wildlife management areas, conservancies, sanctuaries and ranches. Maasailand is unique in being home to some of the Earth's last remaining large wildlife populations, some grazing side by side with livestock owned by the Maasai pastoralists and agro-pastoralists. Wildlife revenue is already common in some of the areas such as Amboseli, Kitengela and Maasai Mara (Thompson 2002; Radeny et al. 2007; BurnSilver 2009; Nelson et al. 2009; Nkedianye et al. 2009; Thompson et al. 2009) and is spreading to the others (Sachedina 2008; Sachedina and Nelson 2012).

Yet, these places are undergoing rapid changes, including in population growth, land privatization, inmigration of non-pastoralists, climate change, land use and land cover (Homewood et al. 2004, 2009b).
All four sites have a bi-modal rainfall distribution, which is most pronounced in Amboseli and least marked in the Mara, due to the long (March-May) and short (October-December) rains (Campbell 1999, Western and Nightingale 2003, KMD 2008; Table 1). The total monthly rainfall (2006-2007) was above average in AthiKaputiei but below average in the other three sites (Fig. 2). The Amboseli-Athi-Kaputiei systems are mutually supporting for migrating livestock, wildlife and pastoralists as the rains tend to fall heavily in each of the two sites in alternate seasons. Pastoralists in the two sites thus move periodically from the region where rainfall has failed in one season to the site that has received high rainfall in that season (Nkedianye et al. 2011).

Rainfall seasonality and recurrent droughts force pastoralists to move their livestock periodically in search of water and pastures in all the four sites (Nkedianye et al. 2011; Nkedianye et al. 2019). As land for grazing becomes scarce (due mainly to fragmentation and expanding settlements), livestock movements become more 
Table 1 A summary of the key characteristics of the four study sites showing the area, rainfall, unique conditions and predominant Maasai section

\begin{tabular}{|c|c|c|c|c|}
\hline Characteristics & Amboseli (Kenya) & Kitengela (Kenya) & Maasai Mara (Kenya) & Simanjiro (Tanzania) \\
\hline Area $\left(\mathrm{km}^{2}\right)$ & 8400 & 390 & 6500 & 22,200 \\
\hline $\begin{array}{l}\text { Extent of the } \\
\text { sampled area } \\
\text { in each site }\end{array}$ & $\begin{array}{l}\text { Villages starting from Inkiito } \\
\text { and Inchakita adjacent to the } \\
\text { Amboseli National Park } \\
\text { boundary and extending } \\
\text { northwards to Enkii and } \\
\text { Olchani Arro }\end{array}$ & $\begin{array}{l}\text { Villages extending from the } \\
\text { southern boundary of the } \\
\text { Nairobi National Park to the } \\
\text { Konza-Kajiado-Magadi railway } \\
\text { line (Ilpolosat-Enkirgirri) }\end{array}$ & $\begin{array}{l}\text { Villages starting from Talek near } \\
\text { the Maasai Mara National } \\
\text { Reserve boundary and } \\
\text { extending northwards to Aitong } \\
\text { and part of Lemek }\end{array}$ & $\begin{array}{l}\text { The seven villages of Emboreet, } \\
\text { Meleleki, Inkung, Katikati, } \\
\text { Lolkatial, Lenaitunyo and Esilalei } \\
\text { within the Simanjiro Plains area }\end{array}$ \\
\hline $\begin{array}{l}\text { Average } \\
\text { annual rainfall } \\
\pm 1 S D(\mathrm{~mm})\end{array}$ & $350-600$ & $563 \pm 218$ (range $440-900)$ & $400-1200$ & $747 \pm 204$ (range 650-900) \\
\hline $\begin{array}{l}\text { Predominant } \\
\text { Maasai } \\
\text { section }\end{array}$ & IIKisonko (Iloitokitoki) & IIKaputiei & IIPurko & IIKisonko \\
\hline $\begin{array}{l}\text { Distance from } \\
\text { urban areas } \\
(\mathrm{km})\end{array}$ & 232 km from Nairobi City & 30-90 km from Nairobi City. & $109.5 \mathrm{~km}$ from Narok & $184.5 \mathrm{~km}$ from Arusha \\
\hline $\begin{array}{l}\text { Rural or peri- } \\
\text { urban }\end{array}$ & Rural & $\begin{array}{l}\text { Peri-urban. Increasing pressure } \\
\text { to sell land, milk and beef and } \\
\text { driving diversification. }\end{array}$ & Rural & Rural \\
\hline Land tenure & $\begin{array}{l}\text { Still mostly under communal } \\
\text { (group ranch) system of use } \\
\text { and management. Some } \\
\text { privately owned land, especially } \\
\text { in swamps that are sources of } \\
\text { water for wildlife and livestock } \\
\text { in dry periods. Debate ongoing } \\
\text { on land privatization. }\end{array}$ & $\begin{array}{l}\text { Privately owned land. This site } \\
\text { was the first to be sub-divided } \\
\text { and privatized in } 1986 .\end{array}$ & $\begin{array}{l}\text { Private land with title plus some } \\
\text { communally owned land. } \\
\text { Mostly privatized from } 2000 \text {. }\end{array}$ & $\begin{array}{l}\text { The government of Tanzania } \\
\text { fully owns land but grants user } \\
\text { rights to local villages. } \\
\text { Individual families make } \\
\text { decisions on the desired land } \\
\text { use. }\end{array}$ \\
\hline Land use & $\begin{array}{l}\text { Pastoralism, cultivation in } \\
\text { swamps, mostly by in-migrants } \\
\text { who have bought and fenced } \\
\text { off farms in swamps and wild- } \\
\text { life conservation. }\end{array}$ & $\begin{array}{l}\text { Pastoralism, rapid expansion of } \\
\text { urban settlements, industries } \\
\text { and markets, extensive fencing, } \\
\text { irrigated horticulture, quarrying. }\end{array}$ & $\begin{array}{l}\text { Pastoralism, subsistence and } \\
\text { commercial crop cultivation. } \\
\text { Wildlife conservation in over } 15 \\
\text { wildlife conservancies since } \\
2005-2006 \text {. }\end{array}$ & $\begin{array}{l}\text { Pastoralism, subsistence and } \\
\text { large-scale cereal cultivation, } \\
\text { wildlife conservation, hunting } \\
\text { and gemstone mining, which } \\
\text { influences livestock, wildlife and } \\
\text { cultivation. }\end{array}$ \\
\hline $\begin{array}{l}\text { Land } \\
\text { fragmentation }\end{array}$ & $\begin{array}{l}\text { Moderate, fences are } \\
\text { expanding rapidly, especially } \\
\text { around farms in the swamps. }\end{array}$ & $\begin{array}{l}\text { Extreme, accelerated by land } \\
\text { privatization and rapid land use } \\
\text { developments. Has displaced } \\
\text { wildlife and caused collapse of } \\
\text { extensive pastoralism. }\end{array}$ & $\begin{array}{l}\text { Extreme in some areas due to } \\
\text { rapid expansion of fences, } \\
\text { cultivation and micro-urban set- } \\
\text { tlements. Has caused collapse } \\
\text { of Mara-Loita wildlife migrations } \\
\text { and virtual collapse of extensive } \\
\text { pastoralism and pastoral } \\
\text { commons. }\end{array}$ & $\begin{array}{l}\text { Low, mostly through large-scale } \\
\text { commercial agriculture. }\end{array}$ \\
\hline $\begin{array}{l}\text { Human } \\
\text { population } \\
\text { density }\end{array}$ & $\begin{array}{l}\text { Relatively sparsely populated } \\
\text { with settlements concentrated } \\
\text { around water sources. }\end{array}$ & $\begin{array}{l}\text { High in the urban centres but } \\
\text { relatively low in the rural areas. } \\
\text { Increasing influx of people } \\
\text { from other communities mainly } \\
\text { interested in settling or buying } \\
\text { land. }\end{array}$ & $\begin{array}{l}\text { Relatively low population } \\
\text { density but moderate influx of } \\
\text { people attracted by economic } \\
\text { opportunities created by } \\
\text { wildlife tourism and trade. }\end{array}$ & $\begin{array}{l}\text { Relatively low population } \\
\text { density and low influx of } \\
\text { people from the far-away urban } \\
\text { centres. }\end{array}$ \\
\hline $\begin{array}{l}\text { Income from } \\
\text { wildlife } \\
\text { conservation }\end{array}$ & $\begin{array}{l}\text { Amboseli park fees, wildlife } \\
\text { tourism in conservancies. }\end{array}$ & $\begin{array}{l}\text { Some limited wildlife tourism in } \\
\text { small wildlife conservancies. }\end{array}$ & $\begin{array}{l}\text { Premium tourism destination, } \\
\text { high park fees. Lucrative } \\
\text { tourism income controlled by } \\
\text { small groups of investors and } \\
\text { Narok County Government. }\end{array}$ & $\begin{array}{l}\text { Hunting fees and some tourism } \\
\text { income controlled by the } \\
\text { national government. }\end{array}$ \\
\hline
\end{tabular}

Sources: Njoka 1979, Altmann et al. 2002, Thompson 2002, Lamprey and Reid 2004, Bulte et al. 2006, BurnSilver and Mwangi 2007, BurnSilver 2009, Worden 2007, KMD 2008, Ogutu et al. 2008, 2013, 2014, Reid et al. 2008, Serneels et al. 2009, Nkedianye 2010, Msoffe et al. 2011, Nkedianye et al. 2011, 2019, Said et al. 2016, Bartzke et al. 2018, Mukhopadhyay et al. 2019

frequent (Reid et al. 2008) while the effects of droughts on livestock mortality and local livelihoods worsen (UNEP and GoK 2006; Hastenrath et al. 2007; Mworia and Kinyamario 2008; Ogutu et al. 2008, 2013, 2014).
Human population density in the pastoral areas is typically lower than that in agricultural areas with higher rainfall (Peden 1987). Even so, cultivation is spreading into some semi-arid pastoral lands (Fig. 3). As human 


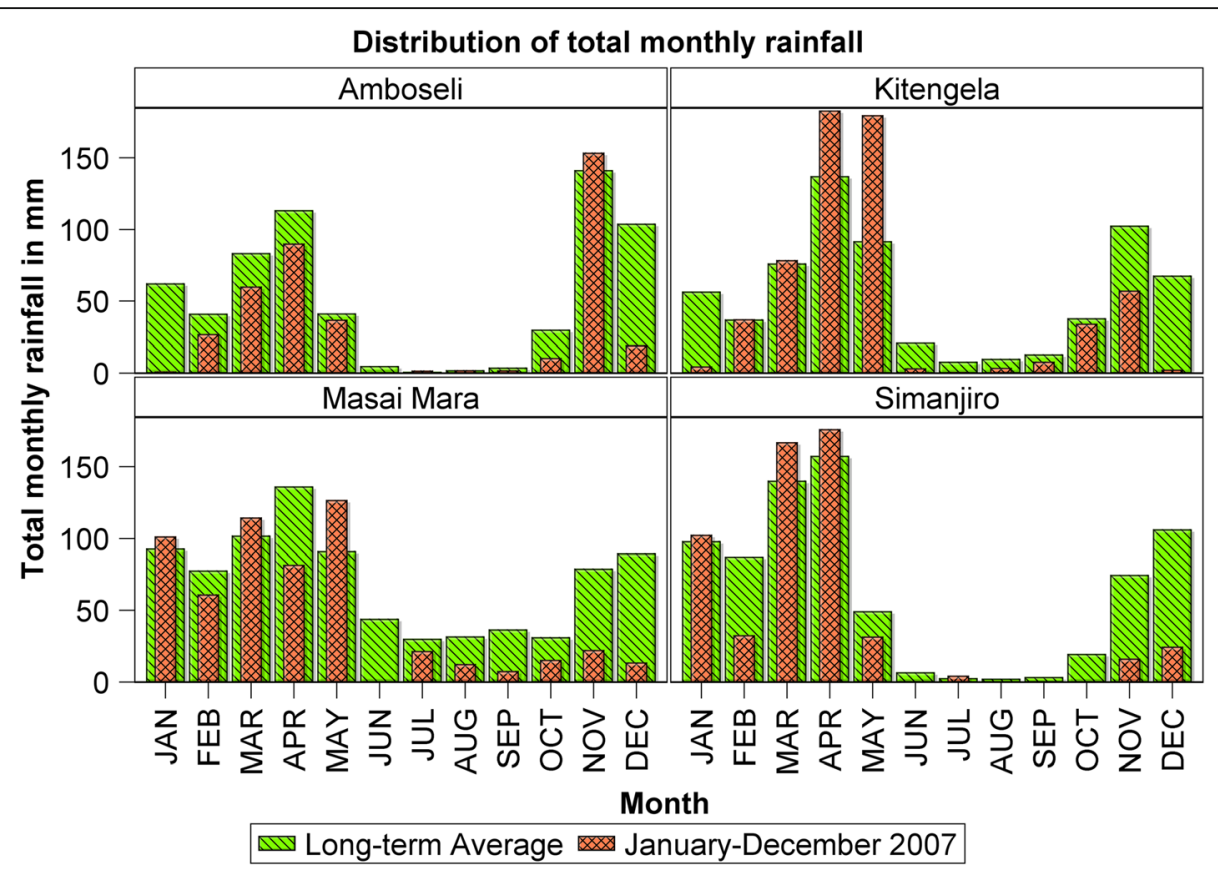

Fig. 2 The distribution of long-term average and total monthly rainfall for January to December 2007 for each of the four study sites (data source: Nkedianye et al. 2011)

population spills into the rangelands and the search for space for cultivation intensifies, the pressure on the rangelands mounts (Fratkin 2001).

The four study sites have undergone various changes, including in land tenure, which are more pronounced in some sites (e.g. Kitengela) while other changes are just beginning to become apparent, especially those due to changing land tenure and use systems (e.g. Simanjiro in Tanzania; BurnSilver 2009, Nkedianye et al. 2009, Sachedina and Trench 2009, Thompson et al. 2009).

The degree of land fragmentation increased with land privatization and distance from major urban centers and so was highest in the fully privatized Kitengela, followed by Masai Mara and Amboseli and least in Simanjiro (Fig. 4).

Historically, all the four sites were used predominantly for rearing livestock by the local Maasai pastoralists because they are mainly semi-humid to semi-arid (Pratt et al. 1966; Njoka 1979).

The main land uses in the Kitengela site include livestock-keeping with free livestock movement, some limited subsistence cultivation and emerging quarrying activities for gypsum and building stones (Kristjanson et al. 2002; Nkedianye et al. 2009). Livestock keeping, wildlife conservation and, increasingly, crop cultivation are the main land uses in Maasai Mara (Serneels and Lambin 2001). In Simanjiro, the major land uses include livestock keeping, crop cultivation (subsistence as well as commercial) and Tanzanite gemstone mining in the
Mererani area (Sachedina 2008). However, in recent years, large-scale cultivation has been on the increase, driven by three main processes: (i) an influx of people from agricultural communities interested in cultivation for commercial and subsistence purposes, (ii) the income from the Mererani Tanzanite mining industry being used to increase and mechanize farming (Borjeson et al. 2008; Sachedina 2008) and (iii) the increasing need for the local people to show ownership of land by cultivating more land as a deterrent to government-led allocation of undeveoped pastoral lands to foreign investors (Sachedina 2008; Homewood et al. 2009a; Sachedina and Nelson 2012). The area is also important for wildlife dispersal throughout the year but most especially during the wet season, when wildebeest (Connochaetes taurinus) and zebra (Eqqus quagga) concentrate and calve there.

\section{Study villages and households}

A household (singular: Olmarei, plural: Ilmareita) among the Maasai is a group of people who live together within the same homestead (in Maa singular, Enkang, plural, Inkang'itie), often managing their livestock together (Kristjanson et al. 2002). The husband is often the household head, and the eldest male member is the head if there is more than one male in the family (Homewood and Rodgers 1991). The locations of the study villages and households are shown in Fig. 5. 

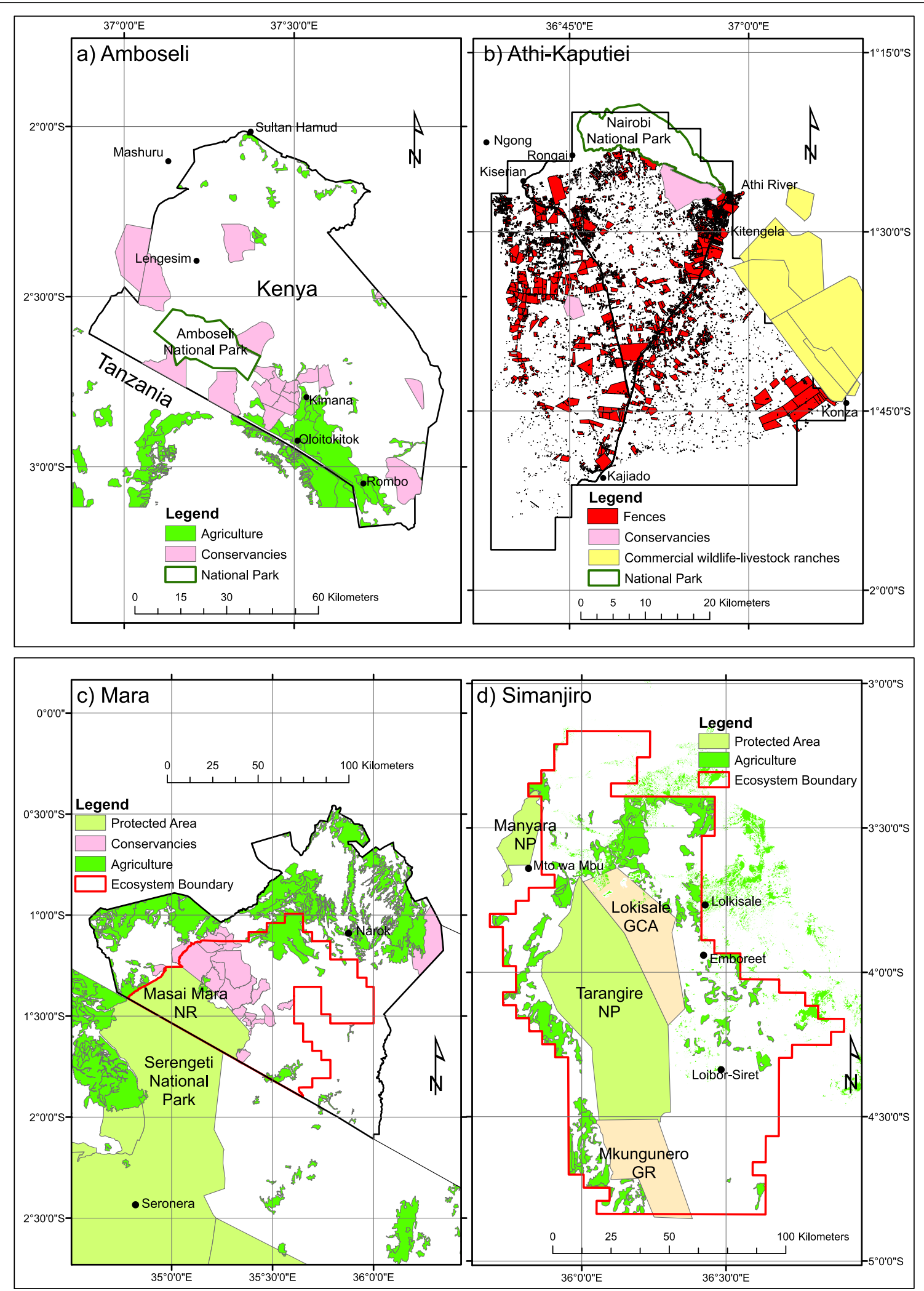

Fig. 3 The four study sites showing the distribution of agriculture, protected areas, wildlife conservancies and commercial wildlife-livestock ranches and land fragmentation by fenced areas and expansion of urban development. a Amboseli. b Kitengela in Athi-Kaputiei. c Maasai Mara. d Simanjiro in Tarangire-Manyara 


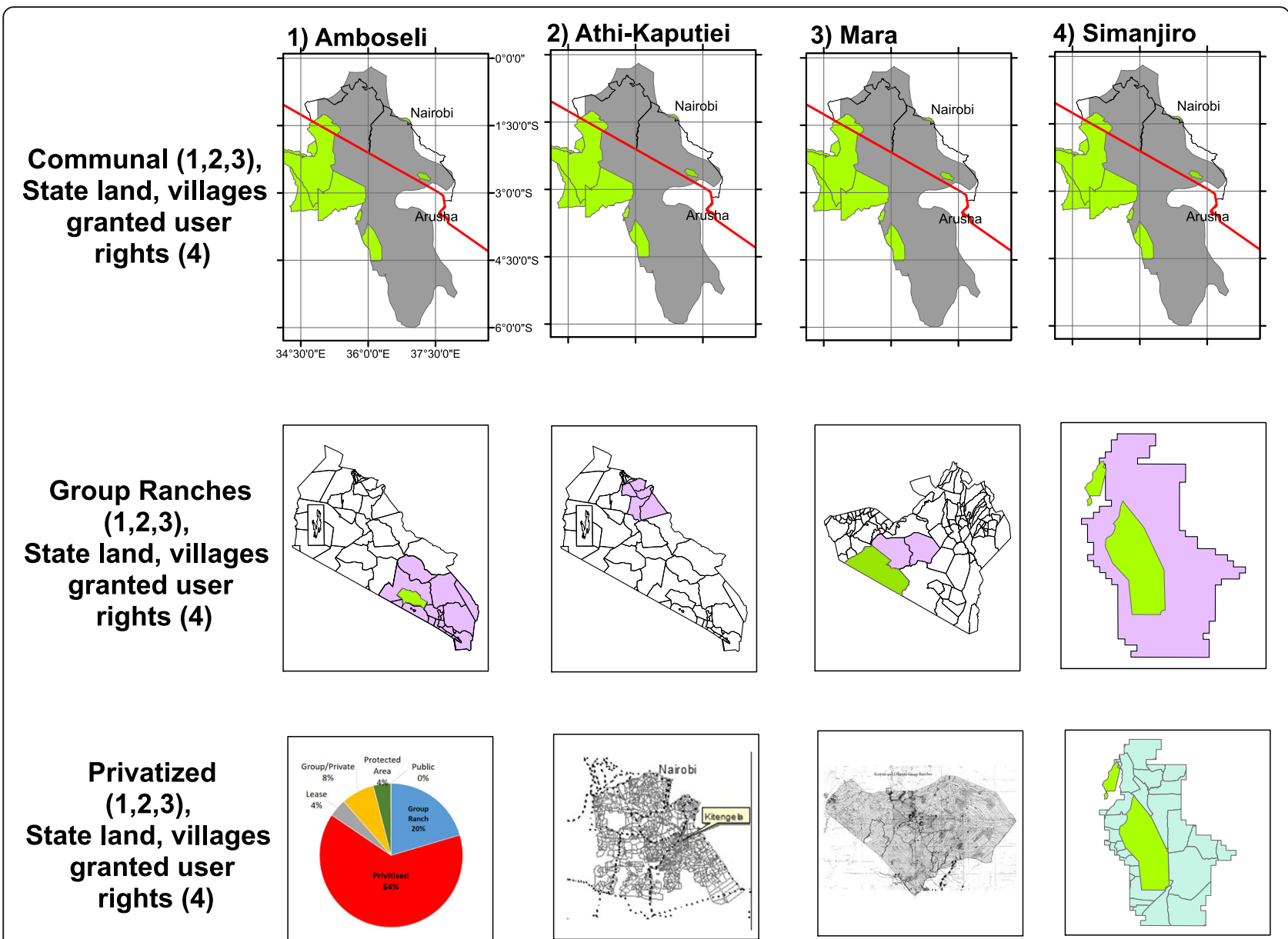

Fig. 4 The four study sites showing increasing level of land fragmentation as land tenure changes from communal to private ownership (after sub-division). The question marks in the final panels for Amboseli and Simanjiro sites denote current uncertainty about future trajectories of land fragmentation

\section{Sampling design and data collection}

A list of all target households was prepared for each site with the help of local Maa-speaking enumerators. Most of the enumerators had previously participated in other data collection activities in their respective sites. The majority had attained an "Ordinary"-level certificate in formal education. The details of the sampling procedure for each site are summarized in Table 2. For each site, the names of 100 household heads were drawn randomly (proportional to the size of the target village) from a list of all the household heads in the target villages at the site. For Kitengela, a list of 888 households enumerated in an earlier study was used (Radeny et al. 2007; Nkedianye et al. 2009). The entire household survey thus consisted of 400 household heads. The full data set used in this paper is provided in S1 Data.

The sample size of 100 households per site was selected to ensure (1) large enough samples representative of each site and (2) that the social-demographic statistics to be compared across sites could be estimated well so that any differences could be reliably established. Each site had many households so that choosing one had little effect on the probability of choosing the next. But budgetary constraints allowed sampling a total of only 400 households. Therefore, we emphasized increasing the reliability of the estimated social-demographic characteristics by sampling 100 households per site rather than distributing the total sample size of 400 in proportion to the total number of households in each site. The latter strategy would have resulted in some sites having fewer sampled households and probably reduced reliability of the estimated socialdemographic parameters.

We recorded the geographical location of each household and personal details of the household head, including the name, age, gender, marital status and years of formal education. We also recorded whether the respondent held a leadership position in an organization, how long the respondent had lived in the location, number of hired herders per household, number of livestock 


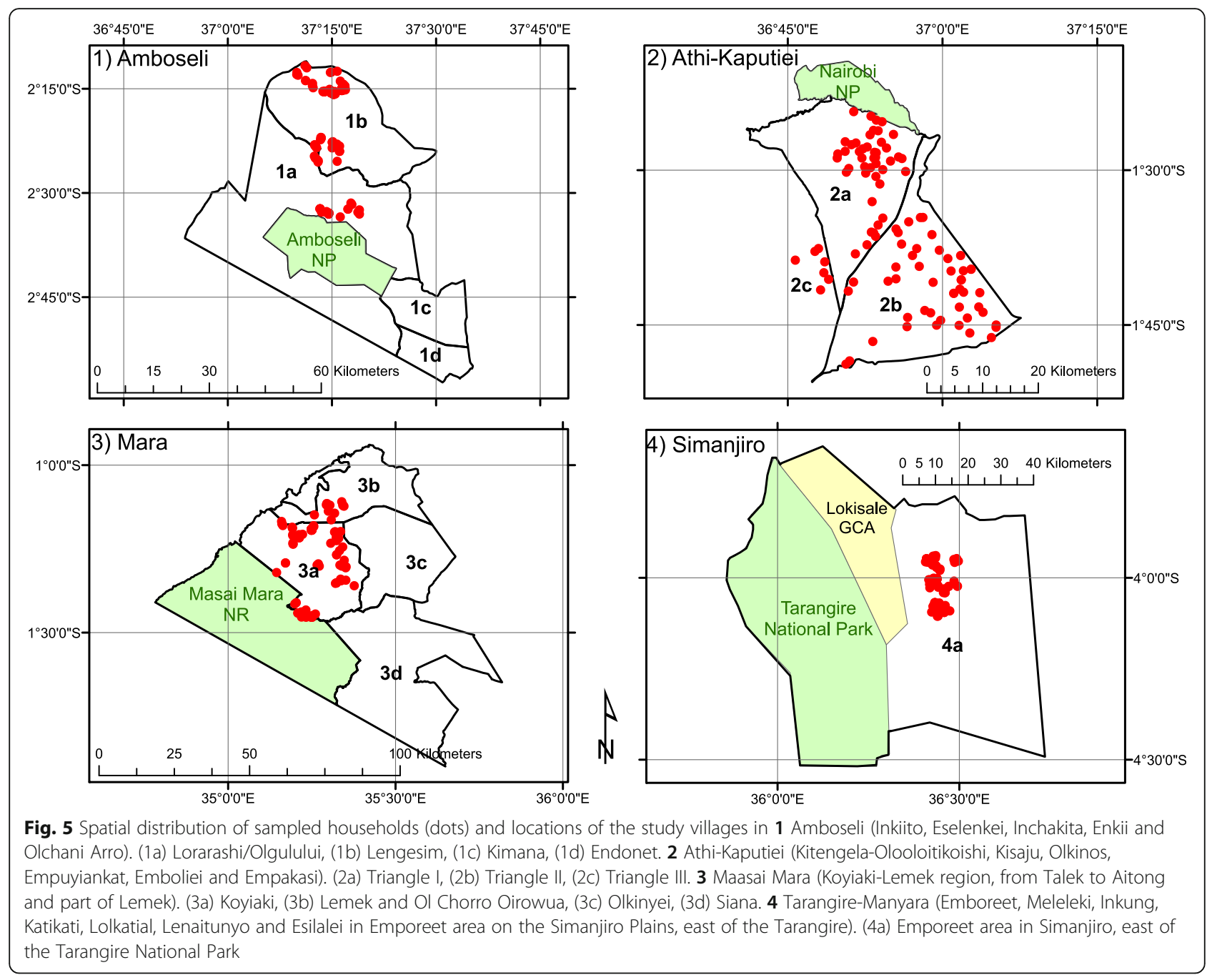

per household, size of the household (broken down by age and sex), number of wives, number of children per wife and number of dependents of the household head who were in school. To assess land ownership and income sources, we recorded the main occupation of the household head, status of land ownership and whether the household was experiencing pasture or water scarcity and strategies used to cope with the scarcity. Regarding crop cultivation, we recorded if the household was cultivating currently and the area of cultivated land, had cultivated in the past or planned to cultivate in the future. To characterize diversification of livelihoods, we recorded and ranked all household income sources. We also recorded responses to the 2005-2006 drought, including livestock movements, sales and mortalities, and other strategies used to cope with the drought. We further recorded households' dependence on, and interaction with, the local protected areas or private wildlife ranches and attitudes towards wildlife. Finally, we recorded the number of households living in the same settlement. All the data were collected within 3 months (May-July 2006), immediately after a severe drought that ended in March-April 2006. The homesteads' locations were captured using a global positioning system (GPS). All the study scientists and enumerators were fluent in Maa, and thus, no translation was required during the interviews. Before the administration of the questionnaires, half a day was spent on pre-testing to ensure that the enumerators fully understood the flow and meaning of the questions and that the questions and their presentation were clear and unambiguous. After pre-testing and revising the questionnaires, the surveys were started the following day.

\section{Statistical analysis}

The household characteristics and their differences or similarities within and across the sites are analysed. The analyses serve as a basis for understanding how households respond to and cope with droughts (Nkedianye et al. 2011). They also aid the interpretation of how 
Table 2 Village clusters in each of the four study sites, the total number of households and number of sampled households from each cluster. A village cluster is a group of neighbouring villages. So, for example, for Amboseli, the villages lloirero, Oltotoi, Olchani Arro, Oltepesi and Inchilishil form one cluster of neighbouring villages

\begin{tabular}{|c|c|c|c|}
\hline Site & Village clusters & All households in cluster & Sampled households in cluster \\
\hline \multirow[t]{4}{*}{ Amboseli (Eselenkei) } & 1. Iloirero, Oltotoi, Olchani Arro, Oltepesi, Inchilishil & 108 & 27 \\
\hline & 2. Enkii, Ng'osuani, Iltuleta, Olobelibel & 91 & 23 \\
\hline & 3. Emisira, Loormong'i, Enchilishili, Olepolos & 111 & 28 \\
\hline & 4. Inkiito, Inchakita & 89 & 22 \\
\hline Sub-total & & 399 & 100 \\
\hline \multirow[t]{3}{*}{ Kitengela (Athi-Kaputiei) } & 1. Oloosirkon, Olooloitikoishi, Sholinke, Kisaju & 403 & 45 \\
\hline & 2. Empatipat, Empuyiankat, Olturoto, Illasit, Enkirgirri, Ilpolosat & 485 & 48 \\
\hline & 3. Nado Enterit & 30 & 7 \\
\hline Sub-total & & 918 & 100 \\
\hline \multirow[t]{4}{*}{ Maasai Mara } & 1. Ng'osuani & 150 & 13 \\
\hline & 2. En'doinyio-e-Rinka & 345 & 30 \\
\hline & 3. Aitong & 299 & 26 \\
\hline & 4. Talek & 161 & 14 \\
\hline Sub-total & & 1150 & 100 \\
\hline \multirow[t]{6}{*}{ Simanjiro (Emboreet) } & 1. Emporeet-Inkung & 31 & 19 \\
\hline & 2. Lalkatial & 21 & 14 \\
\hline & 3. Katikati & 15 & 10 \\
\hline & 4. Esilalei & 20 & 13 \\
\hline & 5. Meleleki & 38 & 26 \\
\hline & 6. Lenaitunyo & 28 & 18 \\
\hline Sub-total & & 153 & 100 \\
\hline
\end{tabular}

households are affected by the internal dynamics of wealth inequalities (Nkedianye et al. 2019). Household characteristics also help highlight the possible trajectories of human activities, challenges and opportunities in landscapes that are under increasing human population pressure. The non-parametric two-sample KolmogorovSmirnov (KS) test was used to perform pairwise comparisons of the frequency distributions of household socialdemographic characteristics across the four sites. The specific social-demographic characteristics compared across the four sites were (1) the number of children per household, (2) the number of households per settlement (Enkang), (3) the age of the household head, (4) the number of wives of the male household head, (5) the number of years of formal education of the household head, (6) the number of hired herders per household and (7) the area of land cultivated per household. Descriptive summary statistics, specifically the mean, median, mode and standard deviation, were also computed for each of the preceding seven social-demographic statistics.

We further analysed factors influencing variation in the seven social-demographic variables, each treated as a response variable. For example, we related the age of the household head to site, gender and their interactions.
The full set of predictors we considered were: site; age, gender and number of years of formal education of the household head; number of wives per male household head; number of children per family; number of herders and area cultivated per household; number of livestock per capita (number of livestock per household/number of all adults and children in the household) and their interactions. For simplicity, we considered only linear and quadratic terms in continuous predictors and permitted only up to 3-way interactions. Not all predictors were considered for each response variable. We used generalized linear mixed models assuming either the normal, gamma or negative binomial error distributions, depending on the response variable. We used the SAS procedure HPGENSELECT to first automatically select predictors and their interactions most strongly correlated with each of the response variables and the Akaike (AIC), corrected Akaike (AICc) and Schwarz Bayesian (BIC) Information criteria and Wald-type chi-squared tests to choose predictors to retain in a model. We assumed a strong hierarchy when doing variable selection, meaning that an interaction term is only retained in a model after the main effects in the interaction have already entered the model. After selecting the predictors, 
we fitted the final model using the SAS GLIMMIX procedure (version 15.1, SAS Institute Inc 2020) and specified random variation between households as a random effect. Pairwise comparisons of adjusted least square means and regression slope coefficients and graphical plots were used to aid the interpretation of interactions. The SAS codes used to fit the models and the full set of predictors and interactions considered for each response variable are provided in S1 Text in the supplementary materials. The predictors and their interactions selected for each response variable are summarized in Table S1 as are the parameter estimates for the predictors retained in the selected final model for each response variable in Table $\mathrm{S} 2$ in the supplementary materials.

\section{Results}

\section{Households' social demography}

\section{Distribution of the respondents' age}

The age of household heads varied significantly across the four sites (Table 3) and averaged 39 years for the Mara, 42 for Amboseli, 46 for Kitengela and 48 for Simanjiro (Fig. 6, Table S1). Pairwise comparisons showed that the average ages of the household heads were similar for Amboseli and Kitengela, Amboseli and Mara and Kitengela and Simanjiro. However, household heads were significantly younger in Amboseli than in Simanjiro and in Mara than in either Kitengela or Simanjiro (Tables S2, S3 \& S4). The frequency distributions of the age of the household head (Fig. 6) were similar for Amboseli and Mara $\left(D_{\max }=0.12, P=0.4611\right)$ but significantly different between Amboseli and Kitengela $\left(D_{\max }=0.19, \quad P=0.0478\right), \quad$ Amboseli and Simanjiro $\left(D_{\max }=0.30, P<0.001\right)$, Kitengela and Mara $\left(D_{\max }=\right.$ $0.28, P<0.001)$, Kitengela and Simanjiro $\left(D_{\max }=0.20\right.$, $P=0.0366)$ and Mara and Simanjiro $\left(D_{\max }=0.3864, P<\right.$ 0.001 ). Also, most households were headed by men regardless of the site. Of the 400 household heads interviewed, $363(90.7 \%)$ were men and only $37(9.3 \%)$ were women.

\section{The prevalence of polygyny across sites}

The average number of wives per household head increased with the age of the household head across all the four sites (Fig. S1) and was twice as high in Simanjiro $($ mean $=2.0$, median $=2)$ as in Kitengela $($ mean $=1.0$, median $=1$ ) but similar between Simanjiro, Amboseli $($ mean $=1.8$, median $=2)$ and Mara $($ mean $=1.8$, median $=2$ ). The frequency distribution of the number of wives per male household head (Fig. S1) was significantly different between Kitengela and Amboseli $\left(D_{\max }=0.45\right.$, $P<0.001)$, Mara $\left(D_{\max }=0.43, P<0.001\right)$ and Simanjiro $\left(D_{\max }=0.46, P<0.001\right)$ but similar among the Mara, Simanjiro and Amboseli sites. Male household heads of similar ages had more wives in Mara and Simanjiro than in either Amboseli or Kitengela and in Mara than in Simanjiro (Tables S5 \& S6). Similarly, the number of wives per household head increased with the number of children per family. Household heads with more children also had more wives across all the four sites. Specifically, for each additional child, male household heads had significantly more wives in Amboseli than in the Mara, Kitengela or Simanjiro but a comparable increase in the number of wives in the Mara, Kitengela and Simanjiro (Tables S5 \& S6).

\section{The number of children per family}

The number of children per family increased with the number of wives per male household head and the number of hired herders per household but decreased with the increase in the number of livestock per capita across all the four sites. More precisely, the number of children per family increased with the number of wives per household head but levelled off at 3 children per wife from 5 wives per household head onward. The frequency distribution of the number of children per family also varied markedly across sites (Fig. S2) and had a significantly higher mean for Simanjiro $($ mean $=8.7)$ than for Kitengela $\left(\right.$ mean $\left.=4.9, D_{\max }=0.35, P<0.001\right)$ or Mara (mean $=6.4, D_{\max }=0.273, P<0.001$ ) but not for Amboseli $\left(\right.$ mean $\left.=7.0, D_{\max }=0.173, P=0.101\right)$. It also differed significantly between Kitengela and Amboseli $\left(D_{\max }=\right.$ $0.272, P=0.001)$ and Mara $\left(D_{\max }=0.222, P=0.015\right)$ but not between Amboseli and Mara, or Amboseli and Simanjiro (Fig. S2). But after adjusting for the number of wives per male household head, the mean number of children per family is comparable across all the four sites (Table S7).

\section{Number of years of formal education of the household heads}

On average, male household heads were more educated than female household heads in all sites (Table S8). Also, the younger household heads were more educated than the older ones, especially in Amboseli and Mara, both of which were comparable, than in Kitengela or Simanjiro; and in Simanjiro than in Kitengela (Table S9). Education level increased linearly with the increasing number of livestock per capita, suggesting that households with more educated heads tended to also have more livestock per capita (Table 3). The average level of formal education of household heads was at least twice as high in the more urban Kitengela as in the other more remote sites (Fig. S3). Specifically, household heads without formal education were the most common in Amboseli (81\%) and the fewest in Kitengela (34\%) but intermediate in the Mara and Simanjiro sites (67\%). The number of years of formal education of household heads averaged 1.4, 6.4, 2.0 and 2.2 for Amboseli, Kitengela, Mara and 
Table $3 \mathrm{~F}$ tests of the significance of factors influencing variation in age, education level (EDU) and the number of wives of household head, number of children per family, number of hired herders and area of cultivated land per household and number of households per settlement across the four study sites in Kenya and Tanzania. NDF and DDF are the numerator and denominator degrees of freedom, respectively

\begin{tabular}{|c|c|c|c|c|c|}
\hline Response variable & Effect & NDF & DDF & $F$ value & $\operatorname{Pr}>F$ \\
\hline Age & Site & 3 & 394 & 8.59 & $<0.0001$ \\
\hline \multirow[t]{5}{*}{ Number of wives of the household head } & Site & 3 & 385 & 8.79 & $<0.0001$ \\
\hline & Age & 1 & 385 & 39.18 & $<0.0001$ \\
\hline & Children & 1 & 385 & 177.46 & $<0.0001$ \\
\hline & Age $\times$ site & 3 & 385 & 10.00 & $<0.0001$ \\
\hline & Children $\times$ site & 3 & 385 & 5.78 & 0.0007 \\
\hline \multirow[t]{4}{*}{ Number of children per family } & Wife & 1 & 390 & 74.54 & $<0.0001$ \\
\hline & Wife $\times$ wife & 1 & 390 & 14.99 & 0.0001 \\
\hline & Livestock_PERHH & 1 & 390 & 6.62 & 0.0104 \\
\hline & Herders & 1 & 390 & 4.95 & 0.0266 \\
\hline \multirow[t]{5}{*}{ Education level of the household head } & Site & 3 & 382 & 22.00 & $<0.0001$ \\
\hline & Gender & 1 & 382 & 46.40 & $<0.0001$ \\
\hline & Age & 1 & 382 & 12.78 & 0.0004 \\
\hline & Age $\times$ site & 3 & 382 & 5.56 & 0.001 \\
\hline & Livestock_PERHH & 1 & 382 & 4.80 & 0.029 \\
\hline \multirow[t]{5}{*}{ Number of hired herders per household } & Site & 3 & 387 & 16.66 & $<0.0001$ \\
\hline & Edu & 1 & 387 & 4.03 & 0.0453 \\
\hline & Children & 1 & 387 & 10.95 & 0.001 \\
\hline & Wife & 1 & 387 & 5.42 & 0.0205 \\
\hline & Livestock_PERHH & 1 & 387 & 27.07 & $<0.0001$ \\
\hline \multirow[t]{8}{*}{ Area of cultivated land per household } & Site & 3 & 377 & 1.26 & 0.2877 \\
\hline & Wife & 1 & 377 & 3.39 & 0.0665 \\
\hline & Wife $\times$ site & 3 & 377 & 3.42 & 0.0175 \\
\hline & Age & 1 & 377 & 2.13 & 0.1456 \\
\hline & Wife $\times$ age & 1 & 377 & 7.51 & 0.0064 \\
\hline & Wife $\times$ age $\times$ site & 3 & 377 & 11.62 & $<0.0001$ \\
\hline & Edu & 1 & 377 & 6.20 & 0.0132 \\
\hline & Edu $\times$ site & 3 & 377 & 4.19 & 0.0062 \\
\hline \multirow[t]{3}{*}{ Number of households per settlement } & Site & 3 & 392 & 9.76 & $<0.0001$ \\
\hline & Wife & 1 & 392 & 8.72 & 0.0033 \\
\hline & Wife $\times$ site & 3 & 392 & 2.10 & 0.0991 \\
\hline
\end{tabular}

Simanjiro, respectively (Fig. S3). The frequency distribution of the number of years of formal education of household heads had a higher mean in Kitengela than in Amboseli $\left(D_{\max }=0.51, P<0.001\right)$, Mara $\left(D_{\max }=0.41\right.$, $P<0.001)$ or Simanjiro $\left(D_{\max }=0.42, P<0.001\right)$ but did not differ between the three other sites.

\section{Number of hired herders per household}

The number of hired herders per household varied significantly across sites and increased with the increasing level of education, number of wives, number of children of the household head and number of livestock per capita. After controlling for these five variables, the mean number of hired herders per household still varied significantly across sites. It was higher for Kitengela than for Amboseli, Mara or Simanjiro, all of which had a similar average number of hired herders (Tables S10 \& S11). That household heads with more wives and children hired more herding labour is intriguing but suggests that such households enrol their children in schools and had more livestock wealth. Hired herders were common in many households in all four sites (Fig. S4). The frequency distribution of the number of hired herders per household was significantly different between Kitengela $($ mean $=1$, 


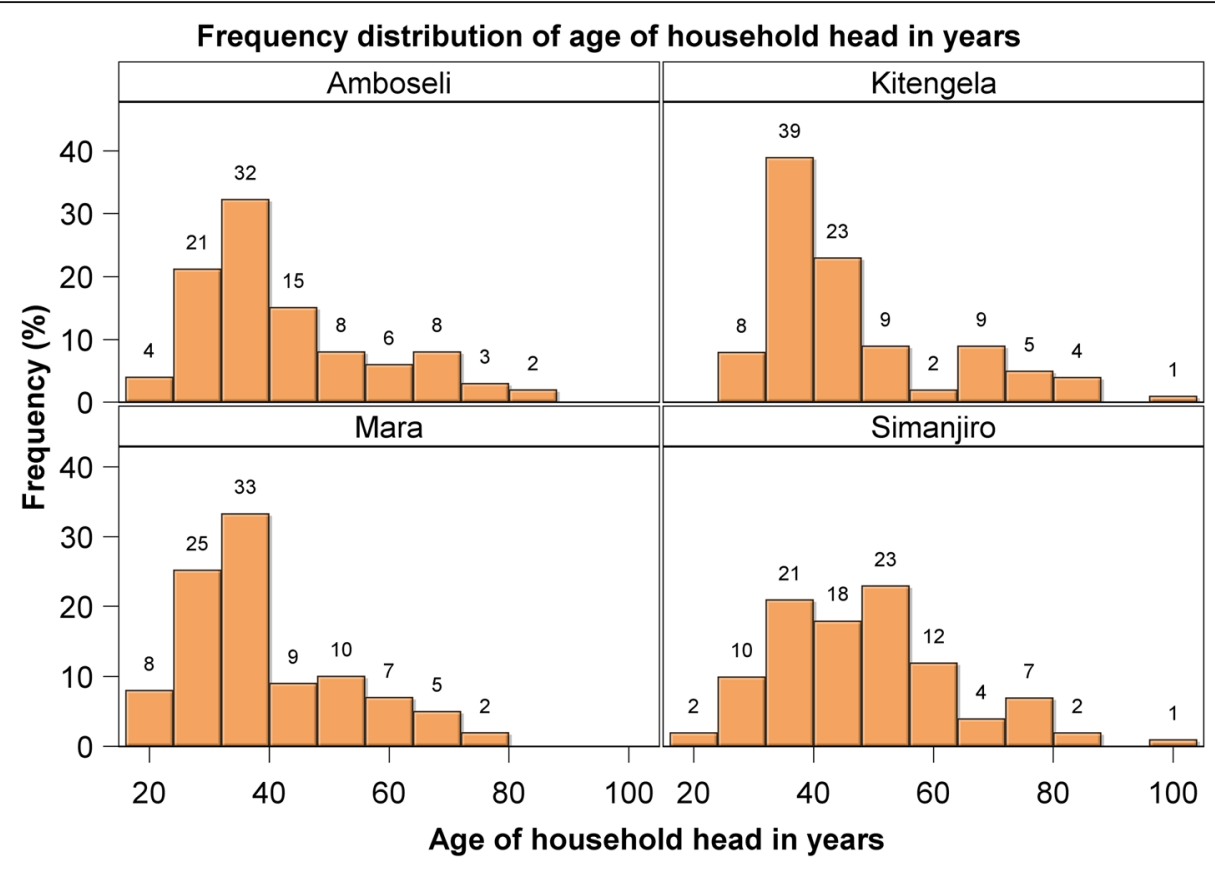

Fig. 6 The frequency distribution of the age of household heads in years in each of the four sites

median $=0$ ) and Mara (mean $=0.4$, median $=0, D_{\max }=$ $0.29, P<0.001$ ), Amboseli (mean $=0.3$, median $=0, D_{\max }=$ $0.42, P<0.001$ ) and Simanjiro (mean $=0.3, D_{\max }=0.4$, $P<0.001)$. The differences among Amboseli, Mara and Simanjiro were insignificant.

\section{Main occupations and diversification of livelihoods}

Livestock keeping was the most widely practised livelihood activity in the four sites and was reported by all respondents as their economic mainstay (Table 4). Subsistence cultivation was only marginally important to respondents in Amboseli, Mara and Kitengela and ranked below trade or business activities in importance. Income from leasing out land for cultivation was the most important in Simanjiro while leasing out land for conservation was practised in Kitengela and Mara but was already being also practised in Amboseli. Few households also reported receiving remittances from family members in all the four sites. Mining and quarrying activities were undertaken in Simanjiro (at Tanzanite Mines in Mererani) and Kitengela (building stone quarries and gypsum mines). The incomes made significant contributions to a small fraction of households (Table 4).

\section{Number of acres under cultivation}

Cultivation was a widespread livelihood activity, but the average area cultivated by a household varied across sites and with the age, level of education of the household head, number of wives and their interactions (Table S2). The cultivated area increased linearly with the number of wives of the male household head and was highest for Simanjiro $($ mean $=14.4$, median $=10)$, intermediate for Kitengela and lowest for Mara and Amboseli. The average number of acres cultivated per household was higher in Simanjiro than in all the other three sites (Fig. S5).

Table 4 Number of households (hhs) engaged in livestock keeping, crop cultivation, trade or business, leasing out land or property, mining or receiving remittances by site

\begin{tabular}{|c|c|c|c|c|c|c|}
\hline Site & $\begin{array}{l}\text { Number of hhs } \\
\text { keeping livestock }\end{array}$ & $\begin{array}{l}\text { Number of hhs } \\
\text { engaged in crop } \\
\text { cultivation }\end{array}$ & $\begin{array}{l}\text { Number of hhs } \\
\text { engaged in trade/ } \\
\text { business }\end{array}$ & $\begin{array}{l}\text { Number of hhs leasing } \\
\text { out land/property }\end{array}$ & $\begin{array}{l}\text { Number of hhs } \\
\text { receiving } \\
\text { remittances }\end{array}$ & $\begin{array}{l}\text { Number of hhs } \\
\text { engaged in mining }\end{array}$ \\
\hline Amboseli & 99 & 38 & 48 & 15 & 7 & 1 \\
\hline Kitengela & 100 & 15 & 29 & 84 & 14 & 9 \\
\hline M. Mara & 100 & 29 & 33 & 19 & 6 & 1 \\
\hline Simanjiro & 100 & 8 & 20 & 98 & 1 & 11 \\
\hline $\begin{array}{l}\text { Percent } \\
\text { of total }\end{array}$ & $100 \%$ & $22.5 \%$ & $32.5 \%$ & $54 \%$ & $7 \%$ & $5.5 \%$ \\
\hline
\end{tabular}


The differences were significant for Kitengela $($ mean $=$ 1.6, median $=2, D_{\max }=0.76, P<0.001$ ), Mara (mean $=$ 0.7 , median $\left.=1.5, D_{\max }=0.92, P<0.001\right)$ and Amboseli (mean $=0.4$, median $\left.=2, D_{\max }=0.93, P<0.001\right)$. The differences among the three Kenyan sites were not significant. Even though the cultivated area generally increased with both the age and number of wives of the male household head, it declined for the very old ( $>75$ years) household heads or household heads with more than 3 wives. This suggests that the very old household heads, who are also the most likely to have the most wives and children and hence the most family labour, tended to practise pastoralism more than agro-pastoralism.

\section{Plans to cultivate in future}

Most household heads expressed interest in cultivating in the future, if favourable conditions allowed, implying that the high rates of abandonment of crop cultivation recorded among the sites was primarily due to periodically unfavourable climatic conditions (Table 5). The highest percentage of respondents that had abandoned crop cultivation were in Amboseli (80\%) and the lowest in Kitengela (6\%). In Mara, 67\% had abandoned cultivation, while in Simanjiro, none had done so.

\section{Land ownership and land tenure status}

Land ownership and tenure arrangements also varied across sites especially between the three Kenyan sites and Simanjiro in Tanzania, reflecting historical differences in land tenure and use policies between the two countries (Table 6). In the Kenya sites, there was a mixture of both communal and private tenure, but with a strong emerging trend towards privatization of land ownership. Land in Kitengela site was fully privatized and individually owned. In Maasai Mara, land subdivision had already been completed but not all land parcels had been titled. Thus, only about a half of those interviewed had titles. The Amboseli (Eselenkei and Olgulului areas) was still within a group ranch system. Unlike their Kenyan counterparts, respondents in Simanjiro lived on government-owned land, but had rights to cultivate and graze their livestock within designated communal areas.
Table 6 Land tenure status for the 400 household heads in the four study sites

\begin{tabular}{lllll}
\hline Site & Private ownership & Group ranch & Government & Total \\
\hline Amboseli & 0 & 100 & 0 & 100 \\
Kitengela & 100 & 0 & 0 & 100 \\
Maasai Mara & 48 & 52 & 0 & 100 \\
Simanjiro & 0 & 0 & 100 & 100 \\
\hline
\end{tabular}

\section{Settlement arrangements}

Households generally formed larger settlements where land was owned communally than where it had been privatized, sub-divided and landowners settled on their individual parcels. The average number of households living in the same settlement was highest in the Mara (mean $=4.4$, median $=4$, range 1-15), intermediate in Amboseli (mean 3.3, median $=3,1-13$ ) and Simanjiro (mean 2.5, median $=2$, range 1-15) and lowest in Kitengela $($ mean $=1.8$, median $=1$, range 1-11) (Fig. S6). The frequency distribution of the number of households per settlement was higher for Mara than for Kitengela (Kolmogorov-Smirnov test, $D_{\max }=0.53, P<0.001$ ) or Simanjiro $\left(D_{\max }=0.34, P<0.001\right)$, for Amboseli than for Kitengela $\left(D_{\max }=0.39, P<0.001\right)$ and Simanjiro $\left(D_{\max }=\right.$ 0.3, $P<0.001)$ and for Simanjiro than for Kitengela $\left(D_{\max }=0.26, P<0.002\right)$. However, the distribution of the number of households per settlement in the Mara and Amboseli was comparable $\left(D_{\max }=0.14, P=0.281\right)$.

The average number of households per settlement increased with the number of wives per household head. After adjusting for the number of wives per household head, the mean number of households per settlement was higher still for Amboseli than for Kitengela or Simanjiro and for Mara than for Kitengela, Amboseli or Simanjiro (Tables S13 \& S14). Moreover, a unit increase in the number of wives per household head was associated with a larger increase in the average number of households per settlement in Mara than in Amboseli or Kitengela and in Amboseli and Kitengela than in Simanjiro (Table S15).

\section{Discussion}

\section{Households' social demography}

Key characteristics of traditional Maasai pastoralism are undergoing profound changes at rates that vary

Table 5 Crop cultivation profile of the studied households

\begin{tabular}{lllll}
\hline Site & Cultivated in the past & Cultivating 'now' & Percentage change & Plan to cultivate in future \\
\hline Amboseli & 59 & 12 & -80 & 86 \\
Kitengela & 85 & 80 & -6 & 88 \\
M. Mara & 88 & 29 & -67 & 91 \\
Simanjiro & 100 & 100 & 0 & 95 \\
Percent of total & 83 & 55 & 28 & 90 \\
\hline
\end{tabular}


regionally. The changes are altering many characteristics that have historically been critical for the survival of the Maasai and their livestock herds, including sharing of pastures, water, labour for herding and other needy situations (Spencer 1998; Rutten 1992; Bekure et al. 1991; Tignor 1972).

Polygyny has been ubiquitous in Maasailand (Talle 1988; Coast 2002; Cochrane et al. 2005) but is changing at regionally disparate rates. It is still widely practised in all the four sites but is on a downward trend and was lowest in the peri-urban Kitengela. Unless more youth from these pastoral areas can find off-land jobs in the urban areas in order to relieve pressure on the rangelands, rapid population growth portends a serious threat to the continued availability of open space for extensive livestock grazing (McCabe et al. 2014) and biodiversity conservation. Polygyny ensured enough labour to look after the livestock, especially during drought periods. More wives and children could share the workload and ensure that the family herd survived (Homewood and Rodgers 1991; Telelia and Spencer 1993; Spencer 2004). In many instances, wealthier men had several satellite homes where additional labour was an advantage (Njoka 1979; Coast 2002). Although polygyny is still widespread across Maasailand, major changes are occurring closer to urban centres most likely due to the influence of outsiders (Holland 1996), education (King 1972) and Christianity (Baird 2015). Polygyny was much less prevalent in Kitengela than in the other sites. Similar rates of change in the prevalence of polygyny were found by earlier studies across Maasailand, including the downward trend (Coast 2002). However, Kitengela is noteworthy in having the lowest prevalence of polygyny, number of wives and children per household head. This is probably the result of Kitengela's proximity to urban areas and increased information (such as on health, education, family planning access for women and higher demand for market-dependent commodities; Ainsworth et al. 1996). The relatively higher cost of living and demand for modern commodities (due to more pronounced market forces in a place such as Kitengela) are exerting greater pressures on households to change in favour of smaller families. The influence of Christianity and opposition from popular western thought are also partly responsible for the decline in the prevalence of polygyny (Hodgson 2004, 2005; Coles 2008; Baird 2015).

The average Maasai household size also varies across sites, from 4 to 8 adult units. Although Kitengela had comparatively smaller families, they are still relatively large and thus can exert considerable pressure on the available resources. The children need basic necessities and, later on, land to settle on. Family size therefore has a direct bearing on the available space and resources in the rangelands. Other studies have also reported a smaller number of children and family size for Kitengela than for other parts of Maasailand (Rutten 1992; Mwangi and Warinda 1999; Kristjanson et al. 2002; Radeny et al. 2007). The mean number of children per family in Kitengela was not only lower than that for the other sites but also lower than that for traditional Maasai households (Njoka 1979; Coast 2002). Part of the reason for fewer children may be the lower number of wives per household head and the pressure exerted on families by commercialization of goods and services associated with proximity to urban centres. The higher cost of living brought about by the cash economy (Kituyi 1990) is also forcing the Kitengela families to have fewer children so that they can better cater for their needs, especially due to the increased demand for education. Government policies on, for example universal primary education, are also felt more in, or closer, to urban areas than in rural areas (Mugisha 2006). The fact that the number of children per family was highest in Simanjiro followed by Amboseli and the Mara reinforces the prediction that changes away from a typical pastoral lifestyle should be greater in Kitengela than in the other sites remote from the main urban areas.

The level of education was also the highest in Kitengela. The other three sites have more or less similar levels of formal education among the household heads. Formal education for children has become desirable for most parents as those with a good education are seen as having better employment prospects (Buchmann 2000). The average number of years of formal education among household heads in Kitengela was significantly higher than that in the other sites and re-affirms a trend noted by previous studies (Radeny et al. 2007; Nkedianye et al. 2009). Attainment of higher levels of formal education was a function of several factors, most of which are absent in remote areas such as Amboseli, Maasai Mara and Simanjiro, leading to continued peripheralization (Hedlund 1979). These include proximity to schools, and parents who appreciate the importance of formal education, are willing to send their children to school and can pay the cost of such education (Buchmann 2000). The main explanation for the higher average level of education in Kitengela is the proximity of the site to urban areas and a major highway (the Great North Road) that cuts across Kitengela. Typically, many schools in pastoral areas have lower enrolments, poorer performance and lower rates of attainment (King 1972, Kituyi 1990, Rutten 1992, Holland 1996).

The trend in Kitengela could be a precursor of what will happen in the other parts of Maasailand and other pastoral areas. The rising education levels, sedentarization and increasing uptake of hired labour pose a dilemma for the Maasai pastoralists. It is desirable and a legal requirement by both the Kenya and 
Tanzania governments for all children to attend school, at least up to secondary school. The trend towards sending all children to school is desirable, but will likely continue to exert increasing pressure on livestock husbandry. Yet, as all the children are sent to school, livestock herding is left at the mercy of hired labour.

In spite of the dilemma children's education presents, it is anticipated that the Maasai will continue enrolling their children for formal education. In the short term, this may seem a problem but in the long run it could have farreaching and favourable benefits to the Maasai as well as at the national level. Notably, the Kenya government's policy of free and compulsory primary education and a 100\% transition from primary to secondary school are accelerating the rate of enrolment across Kenya. Although disparities exist between the rural and urban areas with better access, enrolment and attainment levels, rural areas are also expected to improve as more pastoralists enroll their children in school (Mugisha 2006, Bishop 2007). Overall, formal education levels in Maasailand are still very low relative to the national average (Mwangi and Ostrom 2009). For the Maasai to effectively cope with change, higher education levels will be a pre-requisite as the competition for job opportunities amidst an exponentially growing youthful population is ever-increasing. In addition, education is crucial for the local people to engage in various development activities (Ndemo 2005, Bishop 2007, Johannes 2010). One slow but sure change in pastoralism is that there will be a generation of young Maasai people who will not have gone through the traditional pastoral system because they were in school for a long time and had no livestock or no land (Fratkin and Mearns 2003). If and when this becomes a widespread occurrence, pastoralism in Maasailand would become radically different from what it is today or collapse as is happening in Kitengela, Masai Mara and Amboseli.

\section{Labour for herding}

The cornerstones of the traditional production strategies, such as availability of labour for herding and traditional education, ensured resilience in the pastoral system.

Children were a key source of herding labour in traditional Maasai (Njoka 1979).

But the supply of labour for herding livestock is dwindling across Maasailand mainly due to the increasing enrolment of children in primary schools (Cochrane et al. 2005). Consequently, the demand for higher school enrolment is increasing the demand for herders. There are, however, significant differences among the sites with Kitengela having the highest number of hired herders. For Kitengela, the high herding labour deficit is mainly a result of the high enrolment rates in schools and more job opportunities for the youth in nearby urban centres.
In the other three sites, hired labour is becoming similarly common. The case for Kitengela is a herding labour-related dis-equilibrium due to almost all children being sent to school, creating an acute shortage of herding labour at the family level (Nkedianye et al. 2009). There was at least one hired herder in each of the households, showing that virtually all households were relying on hired labour for herding. Kitengela absorbs many young adults and even children from other Maasai sections who flock to the area after dropping out of school or undergoing circumcision (Dupoto-e-Maa 2005). These young people (mainly boys) end up becoming herders in Maasai homes and watchmen in nearby shopping centres.

Maasai pastoralists in Kenya are hiring not only Maasai but also Kalenjin, Turkana and Samburu herders from Kenya and Tanzanian herders. This has increased the cost of hiring herders. Families are reducing the cost of hiring herders by increasingly fencing in livestock and releasing hired herders during school holidays. Moreover, poor families are more negatively affected as hired herders require money on a regular basis (Bishop 2007). Consequently, poor parents are assuming more herding and domestic duties to fill the gap in labour caused by their children who attend school (Archambault 2011). Typically, mothers look after sheep and goats whereas fathers look after cattle until weekends when children are available. Poor families sometimes also request relatives, neighbours or friends to look after their livestock or distribute their livestock among trusted relatives or friends able to afford herders. Other studies have identified other conditions that may lead to herding labour shortages and how these can affect pastoralism (Mace et al. 1993).

One main challenge presented by this new development in a hitherto traditional set-up is that as livestock owners depend more on hired labour, the time they devote to livestock diminishes. During times of difficulties, such as droughts, and when there is a need to treat livestock, the herders play an increasingly important role in the absence of livestock owners. But, hired herders may be ill-prepared for the tasks and be less committed to doing so especially under difficult conditions, such as droughts. The heavy reliance on hired herders may therefore introduce labour unreliability, higher transaction costs and a suite of inefficiencies that are less pronounced in a more traditional set-up. As herding labour becomes expensive, scarce and unreliable, livestock keeping in more affected areas such as Kitengela could suffer more, especially during school term times, periods of drought and disease outbreaks (Homewood and Lewis 1987; Little et al. 2009). Having hired labour as a key pillar of pastoralism is ushering in a transition to less mobile and less traditional forms of livestock keeping in Maasailand. 


\section{Main occupations and diversification of livelihoods}

Livelihood diversification in Maasailand is driven by manifold factors and processes, including mixing with and learning entrepreneurial skills from in-migrants, livestock losses to recurrent and severe droughts, high cost of schooling and medicine, increasing cash needs and declining livestock numbers per household. Shrinking land for pasture due to increasing population size, settlements, land privatization, sub-division and fencing also drive diversification in Maasailand. Further drivers include sedentarization, intensification of land use, declining livestock productivity, changing lifestyle and food preferences (Lamprey and Reid 2004; Homewood et al. 2009b; Ogutu et al. 2014). In response to low and declining livestock productivity, Maasai pastoralists are introducing heavier, fast maturing but less hardy breeds. This presents a dilemma to the pastoralists as these breeds have higher productivity and market value but higher mortality rates than the traditional breeds (Nkedianye et al. 2011).

Livestock keeping is still the mainstay of the majority of the Maasai in the four sites. There is, however, widespread diversification into other activities in Maasailand, a pattern also noted by other studies (Kristjanson et al. 2002; BurnSilver 2009). Other sources of income range from crop cultivation in all the sites to mining and quarrying (e.g. building stones in Kitengela or precious stones in Simanjiro). More and more pastoralists are engaged in trade and business while others receive rent from buildings they have constructed in urban areas. Many Maasai are also engaged in formal employment (such as teachers, policemen, politicians, wildlife rangers and tour guides). The levels of diversification in the four sites appear related to the levels of education, the proximity to urban centres (with enabling infrastructure), or the local availability of natural resources for exploitation. Other sources of income in the four sites include earnings from wildlife conservation (Thompson and Homewood 2002). Diversification is also catalyzed by large government development projects, such as major roads and railway lines cutting across Kitengela and Narok County in which Maasai Mara is located.

The future well-being of pastoral households may well rest with the level to which diversification into off-land activities will be successful. As population increases, more mouths need to be fed and livestock alone cannot supply enough food and other necessities. There has been a downward trend in the Tropical Livestock Units (TLU) per capita in Maasailand (Lamprey and Reid 2004; Homewood et al. 2009b) and especially after prolonged droughts (Maloiy and Heady 1965; Campbell 1984; Njoka 1979; Lamprey and Reid 2004). Women tend to be even worse off as their levels of education are even lower in most pastoral communities (Talle 1988;
Coast 2002). Although all the respondents were engaged in livestock keeping and considered it as the main source of their livelihood, the market forces will likely continue exerting more pressure on the household economy and probably increasing poverty. New ways need to be encouraged by the government, the private sector and the local people themselves in expanding possibilities for diversification away from livestock-only strategies. Maasai pastoralists are therefore diversifying but their range of options still leaves room for improvement (Thompson and Homewood 2002; Sachedina 2008; BurnSilver 2009; Homewood et al. 2009b; Nkedianye et al. 2009) and supportive government policy would help ensure that pressure is progressively released from the land.

In all the sites, diversification is likely to first spread along mainstream activities such as livestock keeping, leading to trade in purchase and sale of livestock, sale of milk, butcheries, whereas others may depend on available natural resources such as charcoal burning and sand harvesting, or provision of transport (for example bicycles, pick-ups and motor bikes; Homewood et al. 2009b). Even in some remote areas, electricity supply to the shopping centres is opening up opportunities such as for posho (maize flour) mills, while mobile telephone network coverage has made it possible to communicate promptly and even provide money transfer services (Sife et al. 2010; Rutten and Mwangi 2012; Butt 2015). Where water is available, greenhouse vegetable farming is becoming a new venture as the demand for food increases. However, most opportunities for diversification are likely to hinge on increasing levels of education as well as increased access to relevant and timely information (Bishop 2007; Coles 2008; Little et al. 2009). The younger people will venture into new, non-traditional areas from which parents would rather keep off, as formal education prepares younger people to venture into novel areas of entrepreneurship. Higher education therefore acts as a strong catalyst of livelihood diversification among the Maasai as the land becomes fragmented and the space for livestock grazing diminishes. Traditional activities such as cultivation had less potential to generate more employment compared to other technologyrelated options. Other sectors that were not fully tapped were wildlife conservation-related enterprises, land leasing, payment for ecosystem services, tour-guiding and rental house construction, especially if these ventures could be taken up by more men, women and especially the youth. Nkedianye et al. (2019) analyse the role of other factors on diversification, including household wealth and size.

The Maasai are diversifying either out of necessity or in search of additional sources of income. The most diversified households are apparently doing better than the less diversified ones (McCabe et al. 2010; Baird and 
Gray 2014). Whereas diversification is seen as a necessary cushion against widely fluctuating incomes, its prevailing trends and rates may not always be beneficial to the pastoral Maasai. Successful mobile livestock husbandry and the complex tracking of pastures and water for livestock in a traditional set-up is a daunting task that must be given full attention by pastoralists if the practice is to continue (Fratkin and Mearns 2003; Butt 2010; Nkedianye et al. 2011). As people diversify their livelihoods, they end up having less time for livestock, as they settle down and have to attend to their new-found occupations. All the other tasks demand attention and reduce the time previously allocated for livestock keeping. The pastoralists thus become less flexible in tracking pastures and water. Moreover, diversification is often associated with intensification of land use and land fragmentation, such as through fencing, which reduce the range for and mobility of livestock. Hence, the higher the levels of diversification in a pastoral community, the less likely it is for the livestock herds to cope with the demands of mobility and flexibility that ensure their survival in the temporally variable rangeland environments. The wealthy households might cope with the changes by hiring labour for herding. Yet, the poor may not be able to afford to do so and when their livestock numbers fall below minimum thresholds (Nkedinaye et al. 2019), they might be forced out of the pastoral system. As diversification increases, it is likely to bring with it options that might be preferred to pastoralism (especially for the younger people). Diversification into activities incompatible with pastoralism (especially for the poor) may indicate that pastoralism is not sufficiently meeting their needs and they have to seek for additional income elsewhere. For the wealthy pastoralists, diversification may help strengthen their grip on livestock but if they depend on hired labour, their children are less likely to continue with the traditional lifestyles.

Apparently, the most promising ways of diversification include off-land incomes in better salaried jobs and in trade or business activities. Diversification into activities that are heavily dependent on natural resources (such as charcoal burning, sand harvesting and firewood selling) are likely to be transient because these resources are rapidly depleted, ushering in a phase of unprofitability. When this happens, those dependent on such resources must turn to other activities such as minor trade and the provision of services at the household level, including livestock herding. If the youth attain higher education levels, then they and their dependents can become less dependent on livestock in future (Little et al. 2009).

\section{Acreage under cultivation}

Crop cultivation is widespread in Maasailand, signalling a transition from pastoralism to agro-pastoralism. Quite surprisingly, the area cultivated was not related to the per capita livestock wealth. Nkedianye et al. (2019) found no relationship between the likelihood of a household adopting crop cultivation and livestock numbers per household. There was a decline in the practice of cultivation from the past to the present in Amboseli, Kitengela and the Mara but not in Simanjiro. The decline can be attributed to the unreliability of rain-fed agriculture due to erratic and low rainfall that makes it difficult to realize worthwhile harvests (Kristjanson et al. 2002; Thompson 2002; BurnSilver 2006; Worden 2007). Surprisingly, all the respondents in three of the four sites (except Simanjiro) expressed interest in engaging in crop cultivation 'in the future'. This is consistent with most people cultivating once every few years when weather conditions are favourable and so have a high probability of cultivating at least once in the past but a low probability for a particular year. It is unlikely, however, that cultivation will become a widespread activity in both Kitengela and Amboseli where rain-fed agriculture is least likely to succeed except around the swamps in Amboseli and under irrigation in Kitengela. In Amboseli, the importance of grains had been realized during droughts when the government and other relief agencies supply mainly maize, beans and oil to avert starvation among the local people. Additionally, in all the four study sites, ground maize, used mainly in making uji (porridge) or ugali (stiff porridge), formed a staple food for those who could afford it. Pastoralists will likely continue exploring ways of growing their own food especially when the rainy seasons are favourable. But, the practice has the potential to destroy all the swamps in the Amboseli, large areas of Simanjiro and the Mara. In Kitengela, most of the cultivation is dependent on irrigation using underground water, which, in the long run, is ecologically disruptive and unsustainable.

The four sites have divergent drivers of land cultivation. Crop cultivation is contingent upon climate, wildlife depredation and land use policy. Among the three Kenyan sites, Amboseli has the least potential for rainfed crop cultivation as it has the lowest and most unpredictable rainfall. Where land is suitable for cultivation, such as around the base of Mt. Kilimanjaro, the land was already under cultivation mainly by outsiders. Also, many Maasai landowners are leasing out their land parcels at the base of Mt. Kilimanjaro and in swamps to outsiders (Burnsilver 2009; Homewood et al. 2009b). In Kitengela, harvests from cultivation are elusive, failing 3 out of every 4 years because of recurrent severe droughts (Kristjanson et al. 2002). In the Mara, it is likely that if the risk of wildlife depredation (Mukeka et al. 2019) is contained and wildlife conservation does not provide a more attractive income option, then cultivation could continue to spread in many areas where rainfall is 
adequate (Homewood and Rodgers 1991; NortonGriffiths and Southey 1994; Homewood 1995; Serneels and Lambin 2001). Cultivation has good potential in parts of the Mara but has to contend with a high risk of wildlife depredation and low and erratic rains (Serneels et al. 2001; Sitati et al. 2003; Thompson et al. 2009). Cultivation is unlikely to expand substantially in the Mara unless conservation-related and livestock income dwindle.

The rapid spread of cultivation in the Simanjiro plains presents a major challenge to both livestock pastoralism and wildlife conservation. The Simanjiro site is unique because government ownership of land and land use policy create insecurity in land ownership. By cultivating the land, use can be proved and so the government cannot allocate the land, at least in theory, to other users. Besides, Tanzania has advocated a policy of food selfsufficiency since Independence, which may have contributed to the rapid spread of crop cultivation. Whereas the policy was quite appropriate in the high potential agricultural areas, the same wave of cultivation had spilled over to marginal lands that are least suitable for crop cultivation (Sachedina 2008; Sachedina and Trench 2009). Cultivation in the Simanjiro site is also driven by money from the nearby mining industry (Sachedina 2008). Even so, crop cultivation in Simanjiro is unlikely to be sustainable because of low rainfall (Prins 1992; Prins and Loth 1988), increasing competition for space and the nature of soils in the rangelands.

Although cultivation has been practised since the 1970s, the average cultivated area is relatively low in all the sites. Furthermore, rapidly spreading cultivation, such as in the Simanjiro plains, presents a serious threat to livestock and wildlife grazing land. A challenge presented by cultivation that could potentially increase with time is the multiplicity of the small cultivated parcels as human population increases (Thompson and Homewood 2002). Over time, the small parcels coalesce to form expansive mosaics of fences, cultivated lands and settlements able to displace and restrict livestock and wildlife mobility. The costs and conflicts due to wildlife depredation will likely continue to be a key issue of concern in all the four sites in the future.

Spatial planning, including zoning pastoral lands, is critical to avert a crisis situation already underway and secure land for pastoralists and their herds and wildlife in the rangelands. To sustain production in the rangelands, the socio-ecological integrity of the pastoral system must be maintained and enhanced through sound land use and tenure policies. Policies friendly to pastoralism should be promoted to help save the rangelands and their biodiversity. The absence of such policies and unrestrained economic forces are already driving massive conversion of these critical lands (Ogutu et al.
2013, 2014; Said et al. 2016), leading to rising poverty and biodiversity loss. Given their low average levels of education, more Maasai pastoralists are likely to depend on relief food support, which is not sustainable. In addition, the customary institutions that enhanced resilience, such as mutual support for kin and friends, need to remain robust to enhance sustainability of the pastoral system. These will become even more critical if climatic change causes more frequent and severe droughts or extreme and unpredictable rainfall in the pastoral lands as have been experienced in recent times.

\section{Land ownership and land tenure status}

The question of land tenure in the pastoral areas will continue to be a critical one for a long time. The greatest risk to the pastoral way of life is the loss of grazing lands. As land ownership changes, so also does the chance for land use change increases. An important driving force for the changes in Kenya is therefore government policy on land tenure and use. Privatization of land tenure triggered a sequence of unprecedented changes that now severely threaten traditional pastoralism and biodiversity conservation in Masailand, most critically in Kitengela, where land was privatized earlier than in the other sites (Rutten 1992; Kimani and Pickard 1998; Gichohi 2000). Generally, land privatization has had negative effects on pastoralism as much land has been sold, leading to rapid and sometimes fraudulent land transfers (Munei and Galaty 1999). Land is commonly sold to non-pastoralists who fence and convert it from pasture to other uses incompatible with pastoralism and conservation, including cultivation, ranching and high-density settlements.

Fragmentation, large-scale and subsistence cultivation and fences all increase with privatization of land tenure (Mwangi 2007a, 2007b; Said et al. 2016). Thus, as the few group ranches left in southern Kenya become subdivided into privately owned parcels, more land sales will almost certainly occur (Galaty 1992; Rutten 1992). After land privatization, titling and sub-division, large parts of Kitengela have undergone such extreme land fragmentation and land use developments (Ogutu et al. 2013; Said et al. 2016) that pastoralism has been all but exterminated. Masai Mara and Amboseli are following suit, with fences and settlements expanding at unprecedented and accelerating rates and scales (Okello and D'amour 2008; Kioko et al. 2008; Løvschal et al. 2017). For example, following land privatization, sub-division, fencing and land use intensification in Maasai Mara, many pastoralists are keeping and watering their livestock and growing grass fodder inside fences. In northern Tanzania, land tenure is less likely to change soon, but the policies governing land use will continue to influence changes in pastoral 
lands due to widespread cultivation driven by both pastoralists and immigrants from agricultural communities.

Where the land is government-owned but the decisions on land use are made by the local people (Goldman 2006; Sachedina 2008), such as in Simanjiro, government land tenure policies and human population growth will continue to feature among the greatest push factors for land use change as more pastoralists engage in cultivation to lay claim to land parcels either by themselves or by renting out the land. Conversion of grazing land into crop fields will therefore continue to present the greatest threat to pastoralism in Simanjiro. Wildlife conservation is being adversely affected as more traditional wildlife grazing, calving and dispersal areas are converted into subsistence and commercial croplands (Mwalyosi 1992; Sachedina 2008; Msoffe et al. 2019). In Kenya, land tenure is similar in Kitengela and Maasai Mara sites and land is now fully privatized with individuals owning title to their land (Thompson 2002; Nkedianye et al. 2009). However, the two areas were about a decade and a half apart in the privatization process because sub-division took place in the mid-1980s in Kitengela but from around 2000 in the Mara. It is possible that land sub-division occurred earlier in Kitengela because it is much closer to Nairobi City so that much of the land fragmentation and conversion activities there were the spill-over effects of the pressure from the rapidly expanding urban centres. In the Mara, higher rainfall and proximity to the world-renowned Maasai Mara National Reserve are important influential factors driving land use change. In Amboseli, the sub-divided small land parcels have almost all been bought off by inmigrants mainly from the agricultural communities. These parcels also happen to have the greatest potential in terms of rainfall and proximity to water. The rest of the un-sub-divided lands lie in the drier belts where livestock keeping is the most suitable land use (Thompson 2002). Hence, privatization of land tenure is pushing many Maasai pastoralists to the drier rangeland margins, accelerating the fragmentation and the demise of extensive pastoralism in Maasailand.

\section{Settlement arrangements}

The traditional Maasai settlement patterns are changing from having many households living together to many settlements with fewer households, or single households (Coast 2002). The trend towards fewer people per settlement is driven by demographic, land use and tenure policies that promote sub-division of land to individual title. As families spread over the landscape, land fragmentation increases and pasture land shrinks. In Kenya, most family members who are allocated their share of land after land privatization tend to prefer moving and starting their own homes on their privately owned land
(Burnsilver 2009; Nkedianye et al. 2009; Thompson et al. 2009). As a result, there is a trend towards fewer households per settlement. Accordingly, more households live in the same Enkang where the land is communally owned than where it is individually owned (Coast 2002, Lamprey and Reid 2004; Meinzen-Dick and Mwangi 2009). But in Simanjiro, it is the need to lay claim to some parcel of the government-owned land that is the major driving force for the dis-aggregation of households (Sachedina and Trench 2009; Sachedina and Nelson 2012). The rapid loss of grazing space to expanding human population, settlements and fences is fundamentally altering and constraining pastoralism (Ogutu et al. 2016). Given that the adult units range from 4 to 8.9 per household across Maasailand, it is probable that unless large masses of people find off-land jobs in the urban centres, or rural industries, there will soon be too little space, making it harder for livestock to track water and forage, thus elevating their sensitivity to widening rainfall variability.

\section{Conclusions}

The Kitengela area stands out as the most different among the four sites. The family sizes are smallest there, household aggregation has declined drastically and the practice of polygyny has gone down more than in the other three sites relative to traditional Maasai society. In addition, land privatization has led to the dispersal of family members so that each one of them lives on their own land as opposed to the traditional way where an extended family and other relatives congregated in one settlement. The education level is highest in Kitengela probably because of greater access to schools and more information on the benefits of formal education. However, it is likely that the lack of family labour will affect other sectors of the pastoral production process, especially livestock herding, thereby necessitating more hiring of herders. Hiring herders could continue growing in all the sites as it is positively related to rising levels of formal education among the youth. Apparently, proximity to urban areas explains the major changes.

As technology uptake advances, the opportunities for diversifying livelihood sources in Maasailand and other pastoral areas will increase. Although some areas are less diversified, all sites show that livestock alone is no longer being taken as the sole livelihood strategy, hence the growing environment-dependent diversification into other strategies. Diversification is critical in pastoral areas as it holds a huge potential for supporting many pastoral households to reduce pressure on the land. It is also clear that with growing demographic pressure in the rangelands, other sources of income to support the higher population numbers will have to be sought. The lack of such opportunities will exert even more pressure 
on the land, increasing human vulnerability and deepening poverty. The departure from traditional strategies that ensured a stable supply of labour for the different herds, and embracing modern ways of dealing with herding labour shortages herald new challenges and opportunities for pastoral communities. However, a growing dilemma is that as modernization is embraced, the opportunity costs will likely increase, resulting in having less time for livestock and a change in community value systems due to dilution by western education and influence. The land tenure change on the Kenyan sites represents the most critical change in contemporary Maasailand. Land sales especially to in-migrants have the potential to significantly reduce the practice of pastoralism as land availability is the most crucial production factor in Maasailand. Unless some planning is urgently done (both in privately-owned lands and in group ranches) to regulate land use, sub-division and fencing, pastoralism and biodiversity conservation will continue to face serious and mounting challenges in the coming decades.

In areas that are already sub-divided such as the Kitengela and Mara, land loss to other uses, but more importantly to outsiders who end up fencing off or cultivating the land, is a critical issue. In Kitengela, the Maasai are already under extreme pressure from outsiders (mainly from agricultural communities) and their ways of life. Apparently, this change may also be viewed as internal, as it essentially emanates from the Maasai people themselves. By selling land, they introduce a raft of factors that negate the proper functioning of the pastoral system. Fences, poultry and flower farms and other land uses incompatible with pastoralism are now ubiquitous in the Kitengela system. Indications are clear that the single most immediate threat to these pastoral systems in southern Kenya is the rapid multiplication of land ownership and the fragmentation that follows land sales (Galaty 1992; Mwangi 2007a, 2007b; Nkedianye et al. 2009). Unless the rate of land fragmentation and sales are reduced, the pastoral way of life and the wildlife in pastoral lands may soon disappear as decreasing mobility heightens livestock and wildlife mortality (Mwangi and Ostrom 2009). Moreover, fencing of large grassland areas hitherto used by livestock and wildlife is progressively constraining their access to water and forage, dispersal and migratory movements.

How then can land fragmentation and sale be reduced? One of the most promising options is the development, approval and implementation of land use master plans for the rangelands and other regions. The plans would guide land use by zoning specific areas for particular uses. These would include urban centres, grazing areas, wildlife conservancies, protected areas and farmland or any other use that may be supported under the prevailing biophysical and socio-cultural conditions. A master plan would also prescribe the minimum size of land below which one cannot sub-divide. However, attempts to introduce a land use master plan have been met with resistance in the past in Kitengela because landowners are extremely reluctant to relinquish part of the privileges of absolute land ownership once limitations on land use are instituted. Landowners also find it undesirable for policy to dictate what sizes of land one can sub-divide. Another problem arises from the children of the landowners who expect to have parcels of their own by way of inheritance (Galaty 1992). Despite these contentious issues, it is difficult to ensure that the pastoral Maasai continue to have land to support their cattle and the necessary movements without imposing stringent guidelines like the land use master plan to hinder fast land fragmentation and conversion. Another key driver of change is the policy on land tenure and use. If the Tanzanian government were to change land use and tenure policies in pastoral areas such as Simanjiro, for example, then the drive to cultivate more and more land would likely slacken, hence reducing the degradation, fragmentation and loss of rangelands for livestock and wildlife (Sachedina and Trench 2009). If the status quo in land use and tenure is maintained, the higher potential grazing lands in the pastoral lands are likely to be lost to settlement and crop cultivation.

If the group ranches in Kenya's Amboseli were to be sub-divided, this would probably be the single most important policy-related change and would strongly hasten the land fragmentation process, leading to loss of space and habitat for wildlife and livestock. This would likely negatively affect local livelihoods and accentuate poverty. Ongoing amalgamation of private lands into wildlife conservancies is helping secure space for wildlife conservation and livestock. Among the greatest threats to the stability of the Amboseli ecosystem is the dwindling supply of water due to rapid conversion of the wetlands. The wetlands are the refuge for the Maasai livestock and wildlife during dry seasons and droughts. The conversion of these wetlands into cropland has greatly compromised the ability of the local Maasai pastoralists and wildlife to cope with recurrent severe droughts (Nkedianye et al. 2011). Overall, more and more Maasai in Amboseli and elsewhere are increasingly recognizing the potential dangers of individually -owned title deeds relative to the fast disappearance of pastoral lands. In both Kitengela and the Mara, the main threat to pastoralism is land sales and the associated expansion of fences and land sub-division into small, economically unviable parcels (Reid et al. 2008; Ogutu et al. 2013, 2014; Said et al. 2016).

Long-term monitoring and studies are needed to accurately characterize the changes that are occurring in Maasai livelihoods and their consequences for 
pastoralism. In particular, the dynamics of land tenure, land use and fragmentation, in the context of rising demographic pressures as well as the role of policy in driving such long-term processes, should be better understood. More regional, as opposed to single site, studies would be critical in advancing our understanding of the wider environmental, demographic and policy influences that underpin the changes. Moreover, the complex impacts of droughts on livestock and livelihoods can be better understood if broad geographic areas are studied so that the implications of the changes for the flexibility and mobility of livestock as well as the influences of future policy directions are assessed in contrasting contexts. The various options available for some pastoral lands to continue to exist as extensive open rangelands for sustainable grazing and biodiversity repositories also need to be explored. In Maasailand and other pastoral systems, land fragmentation and conversions are leading issues. Consequently, strategies seeking to promote the sustainability and resilience of pastoralism and biodiversity conservation should aim to halt or slow down the menace of land fragmentation and conversion by developing and implementing effective land use policies and plans for pastoral rangelands. These should discourage land sub-division, fragmentation and conversion and encourage flexibility and mobility of pastoralists, open, healthy and biodiversity-rich rangelands.

\section{Supplementary information}

Supplementary information accompanies this paper at https://doi.org/10. 1186/s13570-020-00165-2.

Additional file 1. S1 Text: The SAS (Base SAS Version 9.4, SAS/STAT

version 15.1) codes used to select and fit the models and the full set of predictor variables and interactions considered and their subsets selected for each response variable.

Additional file 2: Table S1. Selection of predictors to include in models for each response variable using automatic variable selection with forward selection, the corrected Akaike Information Criterion (AICC) and strong hierarchy criteria for choosing contending models.

Additional file 3: Table S2. Model parameter estimates for the covariates retained in the selected final model for each response variable. Dispersion is the estimate of the scale parameter for the normal, gamma or negative binomial distribution.

Additional file 4: Table S3. Adjusted means for the age of the household head based on the gamma regression with a log link of age on the four study sites. Lower mean and upper mean are $95 \%$ confidence limits of the mean on the original scale. Table S4. Pairwise comparisons of the adjusted means for age of household head between pairs of study sites. Table S5. Estimated slope coefficients for the number of wives per household head based on a gamma regression with the log link of the number of wives per household head on age ${ }^{*}$ site and children*site. Table S6. Pairwise comparisons of the slope coefficients for the regression of the number of wives on site*age and site* ${ }^{*}$ children. Table S7. Estimates of coefficients of the gamma regression with a log link of the number of children per family on the number of wives per household head. Table S8. Estimates of the slope coefficients of the standard normal-theory regression of the number of years of formal education of the household head on gender ( 1 इ Male; $2 \equiv$ Female), age*site and number of livestock per capita. Table $\mathbf{5 9 .}$
Pairwise comparisons of slope coefficients for the regression of the years of formal education of the household head on gender and Site*age. Table S10. Least square means of the number of hired herders per household for each of the four study sites at the mean value of the education level of the household head, number of children per family, number of wives per household head and number of livestock per capita. Table S11. Pairwise comparisons of the adjusted means from the standard normal-theory regression of the number of hired herders per household across sites while holding constant the level of education of the household head, number of children per family, number of wives per male household head and number of livestock per capita. Table S12. Estimates of the slope coefficients from the standard normal-theory regression of the area of cultivated land per household on edu*site and wife*age*site. Table S13. Adjusted means of the number of households per settlement in each of the four study sites computed at the mean value of the number of wives per household head. Table S14. Pairwise comparisons of the adjusted mean number of households per settlement computed at the mean value of the number of wives per household head based on the gamma regression with a log link on site and number of wives per household head. Table S15. Pairwise differences in the slope coefficients from the gamma regression with a log link of the number of households per boma on site, wife and site*wife.

Additional file 5: Figure S1. The frequency distribution of the number of wives per male household head in each of the four sites.

Additional file 6: Figure S2. The frequency distribution of the number of children per family in each of the four sites.

Additional file 7: Figure S3. The frequency distribution of years of formal education of the household head in the four sites.

Additional file 8: Figure S4. The frequency distribution of the average number of hired herders per household in each of the four sites.

Additional file 9: Figure S5. The frequency distribution of the land under cultivation per household in each of the four sites.

Additional file 10: Figure S6. The frequency distribution of the mean number of households (hhs) per settlement in each of the four sites.

Additional file 11: S1 Data. The interview data set used in this paper.

\section{Abbreviations}

NGOs: Non-governmental organizations; KMD: Kenya Meteorological Department; UNEP: United National Environment Programme;

GoK: Government of Kenya; AIC: Akaike Information criterion; AICc: Corrected Akaike Information criterion; BIC: Schwarz Bayesian Information criterion; ANP: Amboseli National Park; NNP: Nairobi National Park; MNNR: Maasai Mara National Reserve; IGR: Ikorongo Game Reserve; GGR: Grumeti Game Reserve; SNP: Serengeti National Park; NCA: Ngorongoro Conservation Area; MGR: Maswa Game Reserve; LMNP: Lake Manyara National Park; LGCA: Lolkisale Game Controlled Area; TNP: Tarangire National Park; MGR: Mkungunero Game Reserve; GPS: Global positioning system; KS: Kolmogorov-Smirnov; EDU: Education level; NDF: Numerator degrees of freedom; DDF: Denominator degrees of freedom; HH: Household; TLU: Tropical Livestock Units

\section{Acknowledgements}

We thank Leah Ng'ang'a and Maren Radeny for technical support. Jane Gitau, Mario Herrero and Ced Hesse read and commented on early versions of this paper. We are grateful to Moses Ole Neselle, Leonard Ole Onetu, Dickson Ole Kaelo and Ogeli Ole Makui for their support during fieldwork and for helping organize field logistics. We also thank anonymous reviewers and the editor for comments and suggestions that helped improve earlier drafts of this paper. We also sincerely thank the field assistants who assisted with the data collection. Joseph Ole Kimiti trained his fellow enumerators on how to use GPS and general data collection activities. Numerous other people, too many to name individually, also helped with the fieldwork. To all we say ashe oleng!

\section{Authors' contributions}

David K Nkedianye coordinated and supervised the field data collection and together with Joseph O. Ogutu drafted the manuscript. Mohammed Y. Said and Shem C. Kifugo prepared all the maps. Robin S. Reid acquired funding 
for fieldwork and oversaw the overall project. All authors edited the manuscript. The authors read and approved the final manuscript.

\section{Funding}

The field research was supported by a grant from the Belgian government (Grant \# DGIC BEL: 011) to the International Livestock Research Institute (ILRI) through the project "Assessing Trade-offs between Poverty Alleviation and Wildlife Conservation"-the Reto-o-Reto Project. JOO was supported by a grant from the German National Research Foundation (DFG; Grant \# 257734638). MYS was supported by the Pathways to Resilience in Semi-Arid Economies (PRISE), Project (Project \# 107643-001). This project has received funding from the European Union's Horizon 2020 research and innovation programme under grant agreement No 641918 through the AfricanBioservices Project. The funding bodies played no role in the design of the study and collection, analysis, and interpretation of data and in writing the manuscript.

\section{Availability of data and materials}

All data generated or analysed during this study are included in this published article [and its supplementary information files].

\section{Ethics approval and consent to participate}

All participants voluntarily consented to participate in the study after the goal of the project had been explained to each of them. No formal ethics approval was required for this study in either Kenya or Tanzania.

\section{Consent for publication}

Not applicable

\section{Competing interests}

The authors declare that they have no competing interests.

\section{Author details}

${ }^{1}$ International Livestock Research Institute, P.O. Box 30709, Nairobi 00100 Kenya. ${ }^{2}$ Centre for the Study of Environmental Change and Sustainability, School of Geosciences, University of Edinburgh, Edinburgh, Scotland, UK. ${ }^{3}$ University of Hohenheim, Institute for Crop Science-340, Biostatistics Unit, 70599 Stuttgart, Germany. ${ }^{4}$ Kenya Market Trust, 14 Riverside, Cavendish Block 3rd Floor, Suite B, Riverside Drive, P.O. Box 44817, Nairobi 00100, Kenya. ${ }^{5}$ Center for Sustainable Drylands Ecosystems and Societies, University of Nairobi, P.O. Box 30197, Nairobi 00100, Kenya. ${ }^{6}$ Northern Rangelands Trust, Private Bag, Isiolo 60300, Kenya. ${ }^{7}$ Department of Ecology and Soil Science, Baku State University, AZ 1148 Baku, Azerbaijan. ${ }^{8}$ Center for Collaborative Conservation and Department of Ecosystem Science and Sustainability, Colorado State University, Fort Collins, CO, USA.

Received: 26 September 2019 Accepted: 23 March 2020 Published online: 06 August 2020

\section{References}

Ainsworth, M., K. Beegle, and A. Nyamete. 1996. The impact of women's schooling on fertility and contraceptive use: A study of fourteen sub-Saharan African countries. The World Bank Economic Review 10 (1): 85-122.

Altmann, J., S.C. Alberts, S.A. Altmann, and S.B. Roy. 2002. Dramatic change in local climate patterns in the Amboseli basin, Kenya. African Journal of Ecology 40 (3): $248-251$

Archambault, C.S. 2011. Ethnographic empathy and the social context of rights: "Rescuing" Maasai girls from early marriage. American Anthropologist 113 (4) 632-643.

Baird, T.D. 2015. Conservation implications of the diffusion of Christian religious ideals in rural Africa. Population and Environment 36 (4): 373-399.

Baird, T.D., and C.L. Gray. 2014. Livelihood diversification and shifting social networks of exchange: A social network transition? World Development 60: $14-30$

Bartzke, G.S., J.O. Ogutu, S. Mukhopadhyay, D. Mtui, H.T. Dublin, and H.P. Piepho. 2018. Rainfall trends and variation in the Maasai Mara ecosystem and their implications for animal population and biodiversity dynamics. PLoS One 13 (9): e0202814.

Bekure, S., P.N. de Leeuw, B.E. Grandin, and P.J.H. Neate. 1991. The long-term productivity of the Maasai livestock production system. In Maasai herding: An analysis of the livestock production system of the Maasai pastoralists in Eastern
Kajiado, Kenya, ed. S. Bekure, P.N. De Leeuw, B.E. Grandin, P.J.H. Neate, and and Chapter Ten. Addis Ababa: ILCA.

Bishop, E. 2007. Schooling and the Encouragement of Farming Amongst Pastoralists in Tanzania. Nomadic Peoples 11 (2): 9-29.

Borjeson, L., D.L. Hodgson, and Z.Y. Pius. 2008. Northeast Tanzania's disappearing rangelands: Historical perspectives on recent land use change. International Journal of African Historical Studies 41 (3): 523-560.

Brockington, D. 2005. The contingency of community conservation. In Rural resources \& local livelihoods in Africa, ed. K. Homewood, vol. 5, 100-120. Oxford: James Currey Ltd.

Buchmann, C. 2000. Family structure, parental perceptions, and child labor in Kenya: What factors determine who is enrolled in school? Social Forces 78 (4): 1349-1378.

Bulte, E.H., R.B. Boone, and P.K. Thornton. 2006. Wild life conservation in Amboseli, Kenya: Paying for nonuse values. Agricultural and Development Economics Division of the FAO https://vtechworks.lib.vt.edu/bitstream/handle/10919/66 883/2391_Bulte2006_wildlife_conservation_Kenya_no.pdf?sequence=1.

BurnSilver, S. 2009. Pathways of continuity and change: Maasai livelihoods in Amboseli, Kajiado District, Kenya. In Staying Maasai: Livelihoods, conservation and development in East African rangelands, ed. K. Homewood, P. Kristjanson, and P. Trench, 161-208. New York: Springer.

BurnSilver, S., and E. Mwangi. 2007. Beyond group ranch subdivision: Collective action for livestock mobility, ecological viability, and livelihoods. Washington, D. C: Rep. 66, international food policy research institute.

BurnSilver, S.B. 2006. Economic strategies of diversification and intensification among the Maasai Pastoralists: Changes in landscape use and movement patterns, Kajiado District. Kenya: PhD Colorado State University, Fort Collins, USA.

Butt, B. 2010. Seasonal space-time dynamics of cattle behavior and mobility among Maasai pastoralists in semi-arid Kenya. Journal of Arid Environments 74 (3): 403-413

Butt, B. 2015. Herding by mobile phone: Technology, social networks and the "transformation" of pastoral herding in East Africa. Human Ecology 43 (1): 114.

Campbell, D.J. 1984. Response to drought among farmers and herders in Southern Kajiado District, Kenya. Human Ecology 12 (1): 35-64.

Campbell, D.J. 1999. Response to drought among farmers and herders in Southern Kajiado District, Kenya: A comparison of 1972-1976 and 1994-1995. Human Ecology 27 (3): 377-416.

Coast, E. 2002. Maasai socioeconomic conditions: A cross-border comparison. Human Ecology 30 (1): 79-105.

Cochrane, K., D. Nkedianye, E. Partoip, S. Sumare, S. Kirusua, et al. 2005. Family fortunes: An analysis of changing livelihoods in Masailand: Final project report Nairobi: Rep. ZC0275, livestock production program, department for international development, international livestock research institute.

Coles J. 2008. How the formal education system in Kenya is changing the culture of the Maasai community. Theses and dissertations (comprehensive). Paper 862.

Dupoto-e-Maa. 2005. Combating child labour through education: A documentation of best practices. Unpublished Report.

Fratkin, E. 2001. East African pastoralism in transition: Maasai, Boran, and Rendille cases. African Studies Review 44 (3): 1-25.

Fratkin, E., and R. Mearns. 2003. Sustainability and pastoral livelihoods: Lessons from East African Maasai and Mongolia. Human Organization 62 (2): 112-122.

Galaty, J.G. 1992. "The land is yours": Social and economic factors in the privatization, sub-division and sale of Maasai ranches. Nomadic Peoples: 26-40.

Galaty, J.G. 1993. Maasai expansion \& the new East African pastoralism. In Being Maasai: Ethnicity \& identity in East Africa, ed. T. Spear, R. Waller, and and Chapter three, 61-86. London: James Currey.

Galvin, K.A. 2009. Transitions: Pastoralists living with change. Annual Review of Anthropology 38: 185-198.

Gichohi, H. 2000. Functional relationships between parks and agricultural areas in East Africa: The case of Nairobi National Park. In Wildlife conservation by sustainable use, ed. H.H.T. Prins, J. Grotenhuis, and T. Thomas, 141-167. Dordrecht: Springer.

Goldman, M.J. 2006. Sharing pastures, building dialogues: Maasai and wildlife conservation in Northern Tanzania. Ann Arbor: PhD Thesis. University of Wisconsin-Madison

Hastenrath, S., D. Polzin, and C. Mutai. 2007. Diagnosing the 2005 Drought in Equatorial East Africa. Journal of Climate 20 (18): 4628-4637.

Hedlund, H. 1979. Contradictions in the peripheralization of a pastoral society: The Maasai. Review of African Political Economy 6 (15-16): 15-34. 
Hodgson, D.L. 2004. Once intrepid warriors: Gender, ethnicity, and the cultural politics of Maasai development. Bloomington: Indiana University Press.

Hodgson, D.L. 2005. The church of women. Bloomington: Indiana University Press.

Holland, K. 1996. The Maasai on the Horns of a Dilemma: Development and Education, 379. Nairobi: Gideon S. Were Press.

Homewood, K. 1995. Development, demarcation and ecological outcomes in Maasailand. Africa: Journal of the International African institute 65 (3): 331-350.

Homewood, K., P. Kristjanson, and P.C. Trench. 2009a. Changing land use, livelihoods and wildlife conservation in Maasailand. In Staying Maasai? Livelihoods, conservation and development in East African rangelands, ed. K. Homewood, P. Kristjanson, and Pippa Chevenix Trench, One, 1-42. New York: Springer Press.

Homewood, K., and J. Lewis. 1987. Impact of drought on pastoral livestock in Baringo, Kenya 1983-85. Journal of Applied Ecology: 615-631.

Homewood, K., and W. Rodgers. 1991. Maasailand ecology: Pastoralist development and wildlife conservation. Cambridge: Cambridge University Press.

Homewood, K., P.C. Trench, and P. Kristjanson. 2009b. Staying Maasai? Pastoral livelihoods, diversification and the role of wildlife in development. In Staying Maasai? Livelihoods, conservation and development in East African rangelands, ed. K. Homewood, Pippa Chevenix Trench, and P Kristjanson, ten, 369-408. New York: Springer Science + Business Media, LLC 2009

Homewood, K.E., T. Coast, and M. Thompson. 2004. In-migrants and exclusion in east African rangelands: Access, tenure and conflict. Africa 74 (4): 567-610.

Johannes, M.E. 2010. The dynamics of female access to formal schooling among pastoralist communities in Kenya: A case of Turkana district in northwestern Kenya (doctoral dissertation, University of Illinois at Urbana-Champaign).

Kenya Meteorological Department (KMD). 2008. Weather outlook for the MarchMay 2008 "Long-Rains" Season. The East African Standard, 14-3-2008. Nairobi: Republic of Kenya.

Kimani, K., and J. Pickard. 1998. Recent trends and implications of group ranch sub-division and fragmentation in Kajiado, Kenya. The Geographical Journal 164 (2): 202-213.

King, K. 1972. Development and education in the Narok District of Kenya. African Affairs 71 (285): 385-407.

Kioko, J., P. Muruthi, P. Omondi, and P.I. Chiyo. 2008. The performance of electric fences as elephant barriers in Amboseli, Kenya. African Journal of Wildlife Research 38: 52-59.

Kituyi, M. 1990. Becoming Kenyans, 250. Nairobi: Acts Press.

Kristjanson, P., M. Radeny, D. Nkedianye, R. Kruska, R.S. Reid, et al. 2002. Valuing alternative land-use options in the Kitengela wildlife dispersal area of Kenya. Nairobi: International Livestock Research Institute.

Lamprey, H.R., and R.S. Reid. 2004. Expansion of human settlement in Kenya's Maasai Mara: What future for pastoralism and wildlife? Journal of Biogeograpy 31 (6): 997-1032

Lane, C.R. 1994. Pastures lost: Alienation of Barabaig land in the context of land policy and legislation in Tanzania, Nomadic Peoples, Special Issue: The Pastoral Land Crisis: Tenure and dispossession in Eastern Africa 34/35, 81-94.

Lesorogol, C.K. 2005. Privatizing pastoral lands: economic and normative outcomes in Kenya. World Development 33 (11): 1959-1978.

Little, P., A. Aboud, and C. Lenachuru. 2009. Can formal education reduce risks for drought-prone pastoralists?: A case study from Baringo District, Kenya. Human Organization 68 (2): 154-165.

Løvschal, M., P.K. Bøcher, J. Pilgaard, I. Amoke, A. Odingo, A. Thuo, and J.C. Svenning. 2017. Fencing bodes a rapid collapse of the unique Greater Mara ecosystem. Scientific Reports 7: 41450

Mace, R., D.M. Anderson, T. Bierschenk, L. Cronk, I. Kohler-Rollefson, et al. 1993. Transitions between cultivation and pastoralism in sub-Saharan Africa [and comments and reply]. Current Anthropology 34 (4): 363-382.

Maloiy, G.M.O., and H.F. Heady. 1965. Grazing conditions in Kenya's Masailand. Journal of Range Management 18 (5): 269-272.

McCabe, J.T. 2003. Sustainability and livelihood diversification among the Maasai of northern Tanzania. Human Organization 62 (2): 100-111.

McCabe, J.T., P.W. Leslie, and L. DeLuca. 2010. Adopting cultivation to remain pastoralists: The diversification of Maasai livelihoods in northern Tanzania. Human Ecology 38 (3): 321-334.

McCabe, J.T., N.M. Smith, P.W. Leslie, and A.L. Telligman. 2014. Livelihood diversification through migration among a pastoral people: Contrasting case studies of Maasai in northern Tanzania. Human Organization 73 (4): 389-400.

Meinzen-Dick, R., and E. Mwangi. 2009. Cutting the web of interests: Pitfalls of formalizing property rights. Land Use Policy 26 (1): 36-43.
Merzel, C., and J. D'afflitti. 2003. Reconsidering community-based health promotion: Promise, performance, and potential. American Journal of Public Health 93 (4): 557-574.

Msoffe, F.U., S.C. Kifugo, M.Y. Said, M.O. Neselle, P. Van Gardingen, R.S. Reid, and J. de Leeuw. 2011. Drivers and impacts of land-use change in the Maasai Steppe of northern Tanzania: An ecological, social and political analysis. Journal of Land Use Science 6 (4): 261-281.

Msoffe, F.U., J.O. Ogutu, M.Y. Said, S.C. Kifugo, J.D. Leeuw, P. Van Gardingen, R.S. Reid, J.A. Stabach, and R. Boone. 2019. Wildebeest migration in East Africa: Status, threats and conservation measures. BioRxiv: 546747 https://www. biorxiv.org/content/10.1101/546747v1.full.pdf.

Mugisha, F. 2006. School enrollment among urban non-slum, slum and rural children in Kenya: Is the urban advantage eroding? International Journal of Educational Development 26 (5): 471-482.

Mukeka, J.M., J.O. Ogutu, E. Kanga, and E. Røskaft. 2019. Human-wildlife conflicts and their correlates in Narok County, Kenya. Global Ecology and Conservation 18: e00620.

Mukhopadhyay, S., J.O. Ogutu, G.S. Bartzke, H.T. Dublin, and H.P. Piepho. 2019. Modelling spatio-temporal variation in sparse rainfall data using a hierarchical Bayesian regression model. Journal of Agricultural, Biological and Environmental Statistics 24 (2): 369-393.

Munei, K.O., and J.G. Galaty. 1999. Maasai land, law, and dispossession. Cultural Survival Quarterly 22: 4.

Mwalyosi, R.B.B. 1992. Influence of livestock grazing on range condition in southwest Maasailand, northern Tanzania. The Journal of Applied Ecology 29 (3): 581-588.

Mwangi A, Warinda E. 1999. Socio-economic dimensions of sustainable wildlife conservation in the Kitengela wildlife dispersal area. Working Paper.

Mwangi, E. 2007a. Subdividing the commons: Distributional conflict in the transition from collective to individual property rights in Kenya's Maasailand. World Development 35: 815-834.

Mwangi, E. 2007b. The puzzle of group ranch subdivision in Kenya's Maasailand. Development and Change 38: 889-910.

Mwangi, E., and E. Ostrom. 2009. A century of institutions and ecology in East Africa's rangelands: Linking institutional robustness with the ecological resilience of Kenya's Maasailand. In Institutions and Sustainability, ed. V. Beckmann, M. Padmanabhan, and and ten, 195-221. Dordrecht: B.V: Springer science +business media. Springer.

Mworia, J.K., and J.I. Kinyamario. 2008. Traditional strategies used by pastoralists to cope with La Niña induced drought in Kajiado, Kenya. African Journal of Environmental Science and Technology 2 (1): 10-14.

Ndemo, B. 2005. Maasai entrepreneurship and change. Journal of Small Business \& Entrepreneurship 18 (2): 207-219.

Nelson, F., B. Gardner, J. Igoe, and A. Williams. 2009. Community-based conservation and Maasai livelihoods in Tanzania. In Staying Maasai? Livelihoods, conservation and development in East African rangelands, ed. K. Homewood, P.C. Trench, and P. Kristjanson, 299-333. London: Springer.

Njoka, T. 1979. Ecological and socio-cultural trends of Kaputiei group ranches in Kenya. Bekerley: PhD University of California.

Nkedianye, D., J. de Leeuw, J.O. Ogutu, M.Y. Said, T.L. Saidimu, S.C. Kifugo, and R. S. Reid. 2011. Mobility and livestock mortality in communally used pastoral areas: the impact of the 2005-2006 drought on livestock mortality in Maasailand. Pastoralism 1 (1): 17.

Nkedianye, D., J.O. Ogutu, M.Y. Said, S.C. Kifugo, J. de Leeuw, P. Van Gardingen, and R.S. Reid. 2019. Livestock-wealth inequalities and uptake of crop cultivation among the Maasai of Kenya and Tanzania. World Development Perspectives 14: 100106.

Nkedianye, D., M. Radeny, P. Kristjanson, and M. Herrero. 2009. Assessing returns to land and changing livelihood strategies in Kitengela. In Staying Maasai?: Livelihoods, conservation and development in east African rangelands, ed. K. Homewood, P. Kristjanson, C. Pippa, and Chapter Four Trench, 115-149. New York: Springer Science + Business Media.

Nkedianye, D.K. 2010. The Maasai of East Africa: Demographic characteristics, drought-coping strategies, and livestock-wealth inequalities. PhD Thesis. The University of Edinburgh, UK.

Norton-Griffiths, M., and C. Southey. 1994. The opportunity cost of bio-diversity conservation in Kenya. Ecological Economics 12: 125-139.

Ogutu, J.O., N. Owen-Smith, H.P. Piepho, M.Y. Said, S.C. Kifugo, R.S. Reid, and S. Andanje. 2013. Changing wildlife populations in Nairobi National Park and adjoining Athi-Kaputiei Plains: Collapse of the migratory wildebeest. Open Conservation Biology Journal 7: 11-26. 
Ogutu, J.O., H.P. Piepho, H.T. Dublin, N. Bhola, and R.S. Reid. 2008. El Ninosouthern oscillation, rainfall, temperature and normalized difference vegetation index fluctuations in the Mara-Serengeti ecosystem. African Journal of Ecology 46: 1-12.

Ogutu, J.O., H.P. Piepho, M.Y. Said, and S.C. Kifugo. 2014. Herbivore dynamics and range contraction in Kajiado County Kenya: Climate and land use changes, population pressures, governance, policy and human-wildlife conflicts. The Open Ecology Journal 7 (1) https://benthamopen.com/contents/pdf/ TOECOL/TOECOLJ-7-1-9.pdf.

Ogutu, J.O., H.P. Piepho, M.Y. Said, G.O. Ojwang, L.W. Njino, S.C. Kifugo, and P.W. Wargute. 2016. Extreme wildlife declines and concurrent increase in livestock numbers in Kenya: What are the causes? PLoS One 11 (9): e0163249.

Okello, M.M., and D.E. D'amour. 2008. Agricultural expansion within Kimana electric fences and implications for natural resource conservation around Amboseli National Park, Kenya. Journal of Arid Environments 72: 2179-2192.

Peden, D.G. 1987. Livestock and wildlife population distributions in relation to aridity and human populations in Kenya. Journal of Range Management 40: 67-71.

Pratt, D.J., P.J. Greenway, and M.D. Gwynne. 1966. A classification of East African rangelands. Journal of Applied Ecology 3: 369-382.

Prins, H.H.T. 1992. The pastoral road to extinction: Competition between wildlife and traditional pastoralism in East Africa. Environmental Conservation 19 (2): 117-123.

Prins, H.H.T., and P.E. Loth. 1988. Rainfall patterns as a background to plant phenology in northern Tanzania. Journal of Biogeography 15 (3): 451-463.

Radeny, M., D. Nkedianye, P. Kristjanson, and M. Herrero. 2007. Livelihood choices and returns among pastoralists: Evidence from southern Kenya. Nomadic Peoples 11 (2): 31-55.

Reid, R.S., M.E. Fernández-Giménez, and K.A. Galvin. 2014. Dynamics and resilience of rangelands and pastoral peoples around the globe. Annual Review of Environment and Resources 39: 217-242.

Reid, R.S., H. Gichohi, M.Y. Said, D. Nkedianye, J.O. Ogutu, M. Kshatriya, P. Kristjanson, S.C. Kifugo, J.L. Agatsiva, S.A. Adanje, and R. Bagine. 2008. Fragmentation of a peri-urban savanna, Athi-Kaputiei Plains, Kenya. In Fragmentation in semi-arid and arid landscapes: Consequences for human and natural systems, ed. K.A. Galvin, R.S. Reid, R.H. Behnke, and N.T. Hobbs, 195224. Dordrecht: Springer.

Rutten, M., and M. Mwangi. 2012. Mobile cash for nomadic livestock keepers: The impact of the mobile phone innovation (M-Pesa) on Maasai pastoralists in Kenya. In Transforming innovations in Africa, 79-101. Koninklijke: Brill NV.

Rutten, M.M.M. 1992. Selling wealth to buy poverty: The process of individualization of land ownership among the Maasai pastoralists of Kajiado District, Kenya, 1890-1990. Breitenbach: Fort Lauderdale: Saarbrücken [etc.].

Sachedina, H., and F. Nelson. 2012. The development of payments for ecosystem services as a community-based conservation strategy in East Africa. In Integrating ecology and poverty reduction, 149-171. New York: Springer, NY.

Sachedina, H., and P.C. Trench. 2009. Cattle and crops, tourism and tanzanite: Poverty, land-use change and conservation in Simanjiro District, Tanzania. In Staying Maasai? 263-298. New York: Springer.

Sachedina, H.T. 2008. Wildlife is our oil: Conservation, livelihoods and NGOs in the Tarangire ecosystem, Tanzania. PhD Thesis. St. Antony's College, University of Oxford.

Said, M.Y., J.O. Ogutu, S.C. Kifugo, O. Makui, R.S. Reid, and J. de Leeuw. 2016 Effects of extreme land fragmentation on wildlife and livestock population abundance and distribution. Journal for Nature Conservation 34: 151-164.

SAS Institute Inc. 2020. SAS system for windows ${ }^{\oplus 9.4, ~ S A S / S T A T ~ v e r s i o n ~ 15.1 . ~ C a r e y: ~}$ SAS Institute Inc..

Serneels, S., and F. Lambin. 2001. Impact of land-use changes on the wildebeest migration in the northern part of the Serengeti-Mara ecosystem. Journal of Biogeography 28: 391-407.

Serneels S, Herrero Mario, Shauna BurnSilver, Pippa Chevenix Trench, Kath Cochrane et al. 2009. Methods in the analysis of Maasai livelihoods. In Staying Maasai? Livelihoods, conservation and development in East African rangelands, ed. K Homewood, Patti Kristjanson, Pippa Chevenix Trench, Two: 43-67. New York: Springer Science + Business Media.

Serneels, S., M.Y. Said, and E.F. Lambin. 2001. Land cover changes around a major east African wildlife reserve: The Mara Ecosystem (Kenya). International Journal of Remote Sensing 22: 3397-3420.

Sife, A.S., E. Kiondo, and J.G. Lyimo-Macha. 2010. Contribution of mobile phones to rural livelihoods and poverty reduction in Morogoro region, Tanzania. The Electronic Journal of Information Systems in Developing Countries 42 (1): 1-15.
Sindiga, I. 1984. Land and population problems in Kajiado and Narok, Kenya. African Studies Review 27 (1): 23-39.

Siringi, S. 2009. Surge in child numbers strains amenities. In Daily nation Saturday, 7 November 2009. Nairobi: Nation Media.

Sitati, N.W., M.J. Walpole, R.J. Smith, and N. Leader-Williams. 2003. Predicting spatial aspects of human-elephant conflict. Journal of Applied Ecology 40 (4): 667-677.

Spear, T. 1993. Introduction. In Being Maasai: Ethnicity \& identity in East Africa, ed. T. Spear and R. Waller, 1-24. London: James Currey.

Spencer, P. 1998. The pastoral continuum: The marginalization of tradition in East Africa. Oxford: Clarendon Press.

Spencer, P. 2004. The Samburu: A study of gerontocracy. London and New York: Routledge.

Sutton, J.E.G. 1993. Becoming Maasailand. In Being Maasai: Ethnicity \& identity in East Africa, ed. T. Spear and R. Waller II, 38-60. London: James Currey.

Talle, A. 1988. Women at a loss: Changes in Maasai pastoralism and their effects on gender relations. University of Stockholm: Stockholm Studies in Social Anthropology.

Telelia, C., and P. Spencer. 1993. The world of Telelia: Reflections of a Maasai woman in Matapato. In Being Maasai: Ethnicity \& identity in East Africa, ed. T. Spear and R. Waller, vol. VIII, 157-173. London: James Currey.

Thompson, D.M. 2002. Livestock, Cultivation and Tourism: Livelihood choices and conservation in Maasai Mara buffer zones. Ph. D Thesis, 1-183. University College London (University of London).

Thompson, D.M., S. Serneels, D. Kaelo, and P.C. Trench. 2009. Maasai Mara - Land privatization and wildlife decline: Can conservation pay its way? In Staying Maasai: Livelihoods, Conservation and Development in East African Rangelands, ed. K. Homewood, P. Kristjanson, and P. Trench, 77-114. London: Springer.

Thompson, M., and K. Homewood. 2002. Entrepreneurs, elites, and exclusion in Maasailand: Trends in wildlife conservation and pastoralist development. Human Ecology 30 (1): 107-138.

Tignor, R.L. 1972. The Maasai warriors: Pattern maintenance and violence in colonial Kenya. Journal of African History 13 (2): 271-290.

United Nations Environment Programme (UNEP) and Government of Kenya (GoK). 2006. Kenya Drought Impacts on Agriculture, Livestock and Wildlife, 181. Nairobi: United Nations Environment Programme https://wedocs.unep. org/handle/20.500.11822/29651.

Waller, R. 1985. Ecology, migration, and expansion in East Africa. African Affairs 84 (336): 347-370

Western, D., and D.L.M. Nightingale. 2003. Environmental change on the vulnerability of pastoralists to drought: The Maasai in Amboseli, Kenya. In Africa environmental outlook: Human vulnerability to environmental change. London: Earthprint on behalf of the United Nations Environmental Program Available at: http://oceandocs.net/bitstream/1834/436/1/Amboseli_maasai. pdf.

Willis, J. 1999. Enkurma Sikitoi: Commoditization, drink, and power among the Maasai. The International Journal of African Historical Studies 32 (2/3): 339-357.

Worden, J.S. 2007. Fragmentation and settlement pattern in Maasailand: Implications for pastoral mobility, drought vulnerability, and wildlife conservation in an East African savanna. PhD Thesis, 1-295. Fort Collins: Colorado State University.

\section{Publisher's Note}

Springer Nature remains neutral with regard to jurisdictional claims in published maps and institutional affiliations. 